\title{
South American Ordovician phyllocarids (Crustacea, Malacostraca)
}

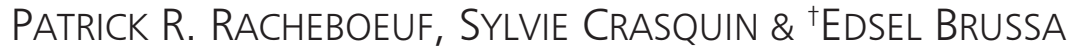

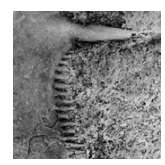

\begin{abstract}
A detailed morphological analysis of exoskeleton remains of the South American Ordovician phyllocarid crustaceans leads to the recognition of a previously unexpected biodiversity from the Tremadocian up to the Katian. As a result, the genus Caryocaris, as up to now understood, clearly appears to be a comprehensive genus. Taxonomically significant characters are listed and discussed. Two new caryocaridid genera are described: Janviericaris gen. nov., and Ivocaris gen. nov. The diagnosis of the Family Caryocarididae is emended accordingly. In addition to the previous description of Caryocaris acuta Bulman, 1931 from Peru, C. bodenbenderi Aceñolaza \& Esteban, 1996 and C. delicata Racheboeuf, Vannier \& Ortega, 2000 from Argentina, seven phyllocarid species belonging to five genera are identified from the Tremadocian up to the Sandbian of Argentina and Bolivia. New caryocaridid representatives are Caryocaris acoitensis sp. nov., Ivocaris saltitensis sp. nov., Janviericaris formosa sp. nov. and J. jujuyensis sp. nov.; three other Sandbian and lower Katian forms are provisionally left in open nomenclature as Caryocaris sp. A to C. Ceratiocaridids are represented by the Upper Ordovician genus Pumilocaris Racheboeuf, Vannier \& Ortega, 2000, with Pumilocaris granulosa Racheboeuf, Vannier \& Ortega, 2000 and Pumilocaris acuta (Bulman, 1931). The familial assignment of the late Tremadocian-Floian genus Rolfecaris gen. nov., represented by Rolfecaris lethiersi sp. nov. and R. parchaensis sp. nov., to the Family Ceratiocarididae still remains uncertain. Caryocaridid phyllocarids have been revealed to be a significantly potential tool for both Ordovician biostratigraphy and palaeobiogeography. Key words: Phyllocarida, crustaceans, biodiversity, biostratigraphy, paleobiogeography, Ordovician, South America.
\end{abstract}

Racheboeuf, P.R., Crasquin, S. \& 'Brussa, E. 2009. South American Ordovician phyllocarids (Crustacea, Malacostraca). Bulletin of Geosciences 84(3), 377-408 (16 figures, 2 tables). Czech Geological Survey, Prague. ISSN 1214-1119. Manuscript received February 26, 2009; accepted in revised form May 27, 2009; published online July 27, 2009; issued September 11, 2009.

Patrick R. Racheboeuf, CNRS - UMR 6538, Domaines Océaniques, Université Européenne de Bretagne, Université de Bretagne Occidentale, Laboratoire de Paléontologie, 6 avenue Le Gorgeu-C.S. 93837, F-29285 Brest cedex 3, France, patrick.racheboeuf@univ-brest.fr•Sylvie Crasquin, CNRS - UMR 7207, CR2P 'Centre de Recherche sur la Paléobiodiversité et Paléoenvironnements', Université Pierre et Marie Curie, Laboratoire de Micropaléontologie, T.46-56, E.5, case 104, F-75252 Paris cedex 05, France; sylvie.crasquin@upmc.fr • ${ }^{\dagger}$ Edsel Brussa, CONICET, Cátedra de Paleontología I, Facultad de Ciencias Exactas y Naturales, Universidad Nacional de La Pampa, Uruguay 151, 6300 - Santa Rosa, La Pampa, Argentina

Field work undertaken since the 2000s, mainly through the Argentina-France scientific programme of cooperation 'Faunes paléozoïques de l'Ouest de l'Argentine' of ECOS-Sud (Action A99U03, 2000-2002) allowed completion of the Ordovician phyllocarid inventory in South America. Previous data from Argentina (Racheboeuf et al. 2000) have been completed by field work in Argentina (2000, 2001) and in Bolivia (2001, 2002). The aim of the present paper is to give an overview of the Ordovician phyllocarid biodiversity in South America and to clarify their stratigraphic range with respect to the graptolite zonation.

The first occurrence of a South American Ordovician phyllocarid crustacean was discovered by Bulman (1931) who described Caryocaris acuta from supposed Caradoc age strata in Peru. Rusconi (1950) described the genus
Mendocaris (type species M. australis, OD) from the Cambrian of western Argentina, the holotype of which (by monotypy) is preserved in the collection of the Museo de Ciencias Naturales de Mendoza (MCNAM) under No. 7556. The specimen was poorly described and not illustrated (as already mentioned by Rolfe in Treatise 1969, p. R326). Revision of the type specimen by one of us (E.B.) confirms that it cannot be formally assigned to any crustacean nor to any other zoological group. Hence the genus name Mendocaris has to be considered a nomen dubium until the discovery of new specimens. More recently, Aceñolaza \& Esteban (1996) described Caryocaris bodenbenderi from the Tremadoc beds of northern Argentina and southern Bolivia, later Racheboeuf et al. (2000) described Caryocaris delicata from Llanvirn strata, and 


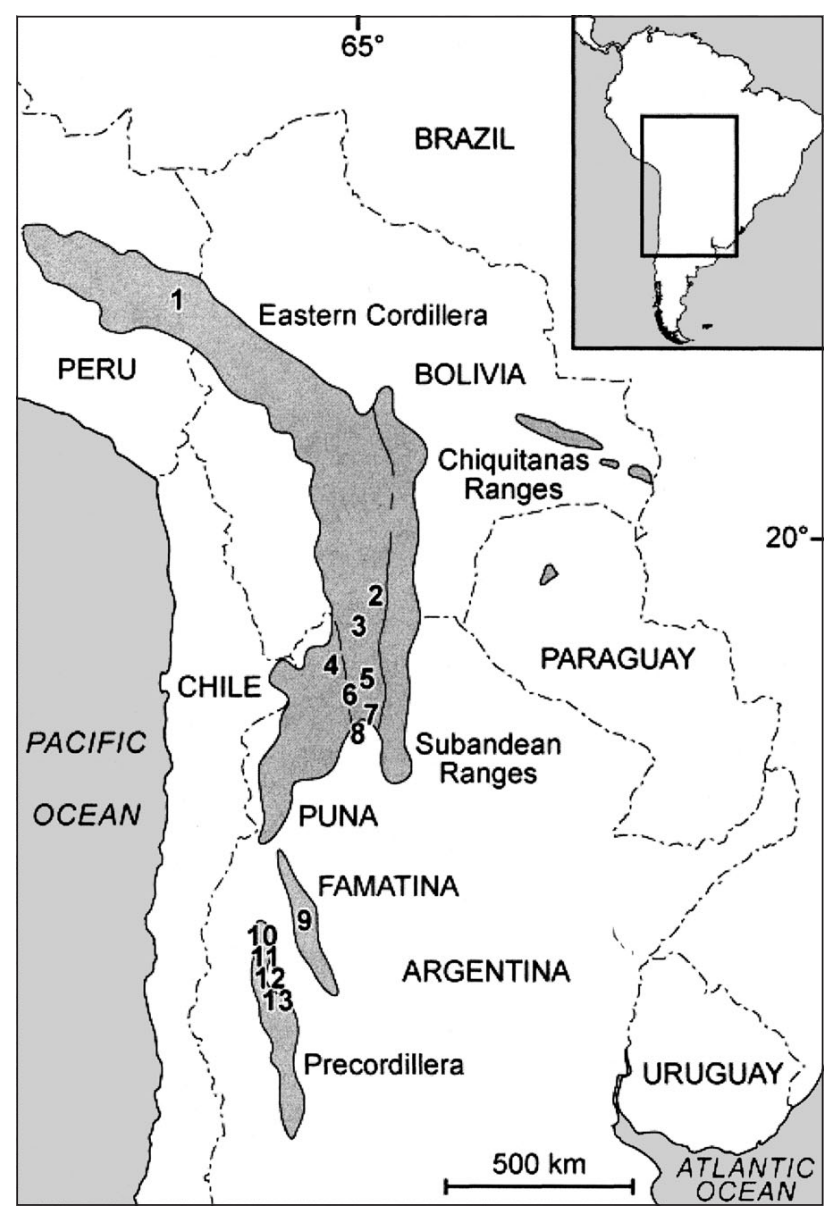

Figure 1. Geographic location of localities from Argentina, Bolivia and Peru listed and sampled in this paper. Peru: 1 - Huichiyuni. Bolivia: 2 - Quebrada de Chapiuno, 3 - Cieneguillas section. Argentina: 4 - Muñayoc Creek, 5 - Los Colorados section, 6-Mina Natasia section, 7 - Agua Blanca Creek, 8 - Parcha-Incamayo Creek, 9 - Portezuelo de la Alumbrera Creek, 10 - Zonja Honda Creek, 11 - Los Saltitos Creek, 12 - Potrerillos hill, 13 - Los Azules Creek.

Pumilocaris granulosa from early Caradoc beds, both from the Argentine Precordillera.

Between 1931 and 2000 numerous South American Ordovician phyllocarid remains have been reported and listed - but rarely illustrated - mainly in open nomenclature as Caryocaris sp., from many localities of Argentina and Bolivia by Harrington \& Leanza (1957), Ahlfeld \& Branisa (1960), Branisa (1965), Aceñolaza (1966), Mendez (1973), Aceñolaza et al. (1976), Súarez-Soruco (1976), Hughes (1980), Ramos (1984), Ortega (1987), Manca (1991), Hannibal \& Feldmann (1996), Racheboeuf et al. (2000) and Legrand-Smith \& Hannibal (2000). Other caryocaridid occurences have been published, such as that of Caryocaris sp. from the upper Llanvirnian beds of the San José Formation of Peru, i.e. in an older level that the Caryocaris acuta of Bulman (Laubacher 1974). Ordovician phyllocarids also occur in the Darriwilian El Higado Formation of the Andean Cordillera Central of Colombia
(Gutiérrez-Marco et al. 2006, p. 624), and Caryocaris sp. was listed from Arenigian levels of the southwestern Llanos of Colombia (Trumpy 1943, p. 1289; Turner 1960; Harrington \& Kay 1951, p. 656). Two recent overviews of Ordovician phyllocarids, partly dealing with South America faunas, have been recently published by Vannier $e t$ al. (2003) and Racheboeuf (2004). All known citations of South American Ordovician phyllocarids drawn from the literature are listed in Table 1 below.

\section{Palaeontological collections}

Specimens from Argentina described and illustrated here are housed in the collections of the Universidad Nacional de Córdoba (UNC, No. CORD PZ), the collections of the Instituto Miguel Lillo of the Universidad de Tucumán (No. PIL) and the Universidad de Mendoza (No. UM). Materials from Peru are housed in the Naturhistoriska Riksmuseum of Stockholm (Sweden) (No. Ar) and those from Bolivia are housed in the Museo de Historia Natural Alcide d'Orbigny in Cochabamba (No. MNHNC).

\section{Localities and stratigraphy}

Ordovician phyllocarid remains have been cited, and/or found and collected in the four main sedimentary basins of the Andean belt: 1) the Central Andean Basin, located in northern Argentina, extending into Bolivia, Chile and Peru, 2) the Famatina Basin, 3) the Precordillera Basin (Fig. 1) and 4) the Central Cordillera of Colombia. We follow criteria by Astini (2003) regarding the Puna, the Cordillera Oriental ('Eastern Cordillera') and the Sierras Subandinas ('Subandean Ranges') within the Northwest Basin although this region corresponds to the southern extent of the Central Andean Basin.

\section{Puna}

The Puna region belongs to the Eastern Eruptive Belt (Faja Eruptiva Oriental) and the phyllocarid Janviericaris jujuyensis gen. et sp. nov. has been collected in three distinct horizons of the Muñayoc section in the west of the Quichagua and Cochinoca Ranges. The fossiliferous black shales belong to the Muñayoc-Cochinoca-Escaya volcanosedimentary Complex. The sections are difficult to measure because of intense folding. The results of facies analysis reveal that the volcano-sedimentary succession record and the upward progression from mudstone-dominated deposits, have to be attributed to deposition under storm and wave influenced processes (Martínez et al. 1999, Coira \& Pérez 2002). Vertical sequences include a range of types from Bouma turbidites-like beds to heterolithics lithofacies dominated by 
Table 1. Citations of South American Ordovician phyllocarid taxa drawn from the literature, from 1931 to 2006. Asterisk indicates type species.

\begin{tabular}{|c|c|c|c|}
\hline $\begin{array}{l}\text { Genera and } \\
\text { species }\end{array}$ & Authors & Range & Country \\
\hline \multicolumn{4}{|c|}{ Family Caryocarididae } \\
\hline Caryocaris & Salter, 1863 & & \\
\hline acuta & Bulman, 1931 & Caradoc & Peru \\
\hline acuta & Camacho, 1975 & Ordovician & Argentina \\
\hline acuta & Súarez-Soruco, 1976 & Llanvirn & Bolivia \\
\hline acuta & $\begin{array}{l}\text { Legrand-Smith \& } \\
\text { Hannibal, } 1996\end{array}$ & ?Arenig & Bolivia \\
\hline acuta & Racheboeuf, 2004 & ?Caradoc & Peru \\
\hline bodenbenderi & $\begin{array}{l}\text { Aceñolaza \& Esteban, } \\
1996\end{array}$ & Tremadoc & Argentina \\
\hline bodenbenderi & Racheboeuf et al., 2000 & Tremadoc & Argentina \\
\hline bodenbenderi & Racheboeuf, 2004 & Tremadoc & Argentina \\
\hline delicata & Racheboeuf et al., 2000 & Llanvirn & Argentina \\
\hline delicata & Racheboeuf, 2004 & Darriwilian & Argentina \\
\hline sp. & Trumpy, 1943 & Arenig & Colombia \\
\hline sp. & Harrington \& Kay, 1951 & Arenig & Colombia \\
\hline sp. & $\begin{array}{l}\text { Harrington \& Leanza, } \\
1957\end{array}$ & Arenig & Argentina \\
\hline sp. & Ahlfeld \& Branisa, 1960 & Arenig & Bolivia \\
\hline sp. & Turner, 1960 & Arenig & Colombia \\
\hline $\mathrm{sp}$. & Branisa, 1965 & Arenig & Bolivia \\
\hline sp. & Aceñolaza, 1966 & Arenig & Argentina \\
\hline sp. & Ramos, 1970 & L-M. Arenig & Argentina \\
\hline sp. & Mendez, 1973 & Arenig & Argentina \\
\hline sp. & Laubacher, 1974 & L. Lanvirn & Peru \\
\hline sp. & Súarez-Soruco, 1976 & Trem./Arenig & Bolivia \\
\hline sp. & Aceñolaza et al., 1976 & Arenig & Argentina \\
\hline sp. & Hughes, 1980 & Trem./Arenig & Bolivia \\
\hline sp. & Ramos, 1984 & Arenig-Llanvirn & Argentina \\
\hline sp. & Ortega, 1987 & Llanvirn & Argentina \\
\hline
\end{tabular}

swell-wave generated ripple cross-lamination. The stacking pattern of the graptolitic sequence, overlapping synsedimentary silicic volcanism, is indicative of increasing accommodation space and restricted sediment supply during a relative sea level rise. The graptolites found in the rhythmites suggest a late early/middle Arenig age.

\section{Eastern Cordillera}

In the thick sections of the Eastern Cordillera region, the phyllocarids are contained in the Acoite and Parcha Forma-

\begin{tabular}{|c|c|c|c|}
\hline $\begin{array}{l}\text { Genera and } \\
\text { species }\end{array}$ & Authors & Range & Country \\
\hline \multicolumn{4}{|c|}{ Family Caryocarididae } \\
\hline sp. & Manca, 1991 & Tremadoc & Argentina \\
\hline sp. & $\begin{array}{l}\text { Aceñolaza \& Esteban, } \\
1996\end{array}$ & Trem.- Llandeil. & $\begin{array}{l}\text { Arg.- } \\
\text { Boliv.-Peru }\end{array}$ \\
\hline $\mathrm{sp}$ & $\begin{array}{l}\text { Hannibal \& Feldmann, } \\
1996\end{array}$ & Arenig/Llanvirn & Bolivia \\
\hline sp. & $\begin{array}{l}\text { Legrand-Smith \& } \\
\text { Hannibal, } 2000\end{array}$ & Arenig & Bolivia \\
\hline sp. & $\begin{array}{l}\text { Gutiérrez-Marco et al. } \\
2006\end{array}$ & Darriwilian & Colombia \\
\hline sp. 1 & Racheboeuf et al., 2000 & L. Arenig & Argentina \\
\hline sp. 1 & Racheboeuf, 2004 & L. Arenig & Argentina \\
\hline sp. 2 & Racheboeuf et al., 2000 & Caradoc & Argentina \\
\hline sp. 2 & Racheboeuf, 2004 & Mohawkian & Argentina \\
\hline sp. 3 & Racheboeuf, 2004 & L. Darriwilian & Argentina \\
\hline \multicolumn{4}{|c|}{ Family Ceratiocarididae } \\
\hline $\begin{array}{l}\text { Ceratiocaris } \\
\text { sp. }\end{array}$ & Branisa, 1965 & Arenig & S Bolivia \\
\hline Pumilocaris & Racheboeuf et al., 2000 & & \\
\hline granulosa* & Racheboeuf et al., 2000 & Caradoc & Argentina \\
\hline granulosa & Racheboeuf, 2004 & Mohawkian & Argentina \\
\hline ?sp. & Racheboeuf et al., 2000 & L. Arenig & Argentina \\
\hline ?sp. & Racheboeuf, 2004 & L. Arenig & Argentina \\
\hline \multicolumn{4}{|c|}{ Archaeostraca indet. } \\
\hline $\begin{array}{l}\text { Phyllocarid } \\
\text { undet. }\end{array}$ & Racheboeuf et al., 2000 & L. Arenig & Argentina \\
\hline $\begin{array}{l}\text { Phyllocarid } \\
\text { gen. et sp. nov. }\end{array}$ & Racheboeuf, 2004 & L. Arenig & Argentina \\
\hline 'Pre-epipodites' & 'Levy, 1971 & Arenig & Argentina \\
\hline \multicolumn{4}{|c|}{ Questionable Phyllocarida } \\
\hline Mendocaris & Rusconi, 1950 & & \\
\hline australis & Rusconi, 1950 & Cambrian & Argentina \\
\hline
\end{tabular}

tions. The former and the Santa Rosita Formation comprise the Santa Victoria Group. The Acoite Formation is composed of alternating dominantly sandy and shaly packages. The Acoite Formation records Tetragraptus phyllograptoides to Didymograptellus bifidus Zones (Toro 1999). Astini (2003) recognized in this unit a transition from oxygen deficient laminated black shales to increasingly bioturbated green shales punctuated by graded sandy beds with rippled tops that could involve long term environmental changes. This transition is developed between the early to mid Arenig (uppermost $B$. deflexus Zone to lowermost $D$. bifidus Zone). 
Phyllocarids from the Parcha Formation in the region of the Incamayo Creek are late Tremadocian. The Parcha Formation overlies unconformably the middle Tremadoc Saladillo Formation. It is composed of laminated sandstones and greenish-grey shales with interbedded calcareous lenses indicating a shallow marine environment represented by platforms alternating with transgressive systems. Recent studies in the area (Ortega \& Albanesi 2002, Waisfeld et al. 2006) have modified the age of the upper levels of this unit, formerly related to the early Arenig. These studies included graptolites, conodonts, trilobites and palynomorphs. The phyllocarid ?Rolfecaris parchaensis sp. nov. has been collected all along the unit and its range corresponds to the Araenograptus murrayi and Hunnegraptus copiosus Zones (late Tremadoc).

Phyllocarids from the south of Bolivia were found in the Chapiuno section, along the Isacayachi-Culpina road, $61.9 \mathrm{~km} \mathrm{NW}$ of Tarija. The graptolite assemblages permit us to confirm the Azygograptus lapworthi Zone equivalent to the Pseudophyllograptus angustifolius Zone of Baltoscandia.

\section{Famatina}

The Famatina Basin is located between the northern extent of the Precordillera and the Cordillera Frontal to the west and the Sierras Pampeanas region to the east. The Ordovician sections in Famatina are more than 3200 m thick and include (Astini 2003): latest Cambrian to Tremadoc carbonates and siliciclastic rocks, Arenig volcano-sedimentary deposits and Middle Ordovician siliciclastics.

Phyllocarid remains have been collected from three lithostratigraphic units. The oldest one, according to Aceñolaza \& Esteban (1996), is the Tremadocian Volcancito Formation which provided the authors with the species Caryocaris bodenbenderi. However the stratigraphical statement of the Volcancito Fm. was modified (Esteban 2002) and the entire section of the Portezuelo de La Alumbrera, type locality of $C$. bodenbenderi, belongs to the Bordo Atravesado Formation which also yields late Tremadocian conodonts, graptolites, and trilobites (Albanesi et al. 2005). In its type section, the Portezuelo de La Alumbrera section, the lower and middle thirds of the Bordo Atravesado Fm. yield five distinct phyllocarid bearing horizons (Esteban 1996, 1999, 2002; Tortello \& Esteban 1995, 2003; Albanesi et al. 2005, among others). The depositional environment was interpreted by Astini (2003) as relatively deep-water with a well-stratified water column throughout in which fine-grained settling took place in anoxic bottom conditions.

The La Alumbrera Formation of the Famatina Range (Arenigian) yields Caryocaris sp. (Aceñolaza et al. 1976, pl. 2, figs 2, 6, 7). Phyllocarid remains also occur in the
Tetragraptus akzharensis biozone (early Arenigian / basal Floian) of the Portezuelo de las Minitas Formation (Aceñolaza \& Gutiérrez-Marco 2000, p. 20).

\section{Argentine Precordillera}

The Argentine Precordillera (Baldis et al. 1984) is almost $1000 \mathrm{~km}$ length and includes vast regions of La Rioja, San Juan, Mendoza and La Pampa provinces. Astini (1992) divided the Precordillera into western and eastern tectofacies to understand more clearly the lower Paleozoic rock distribution in the Precordillera. The eastern domain is represented by Cambrian-Ordovician carbonates, black shales and clastic facies overlying and the western domain is represented by a thick clastic wedge, including bouldery units and mafic rocks. The studied phyllocarids come from four formations of the eastern tectofacies sensu Astini, namely the Gualcamayo/Los Azules, Las Plantas and Trapiche formations.

In 1984 Ramos summarized the previously published occurrences of Caryocaris sp. in the Argentine Precordillera, most of them being Arenigian. Manca (1991) described Caryocaris sp. from the lower Tremadocian Santa Rosita Formation of the Jujuy Province, before the publication of the first monograph dedicated to the Ordovician South American phyllocarids (Racheboeuf et al. 2000).

Ivocaris delicata (Racheboeuf, Vannier \& Ortega 2000) is one of the most widely distributed phyllocarids along the Los Azules Formation. The outcrops of the Los Azules Formation are exposed along the western flank or the Cerro Viejo anticline, east of Jáchal. This unit has a maximum thickness of 318 meters and is made up mainly of black shale, partly calcareous and partly silicified. The Los Azules Formation was informally divided into three members: lower, middle and upper (Ortega 1987). The lower member is represented by silicified black shales and K-bentonite levels which conformably overlie the San Juan Limestone. Recent analysis of the biostratigraphy, based on graptolites, assigned the lower member to the Undulograptus dentatus and Holmograptus lentus Zones (Darriwilian, Da2/?Da3) (Ortega \& Rickards 2003, Brussa et al. 2003b). The middle member includes thin dark sandstones in its basal part and gray laminated siltstones above. The graptolite assemblages of the middle member belong to the Pterograptus elegans and Hustedograptus teretiusculus Zones (Darriwilian, Da4a and Dab) (Ortega 1987, Brussa et al. 2003). A stratigraphic gap is present between the middle and the upper members of the Los Azules Formation. The graptolites of the upper member were assigned to the Climacograptus bicornis Zone of the late Sandbian.

The change from the San Juan Formation limestones into graptolite-rich, deep-water black shales of the Gualcamayo Formation and the partly equivalent Los Azules 
Patrick R. Racheboeuf et al. • South American Ordovician phyllocarids

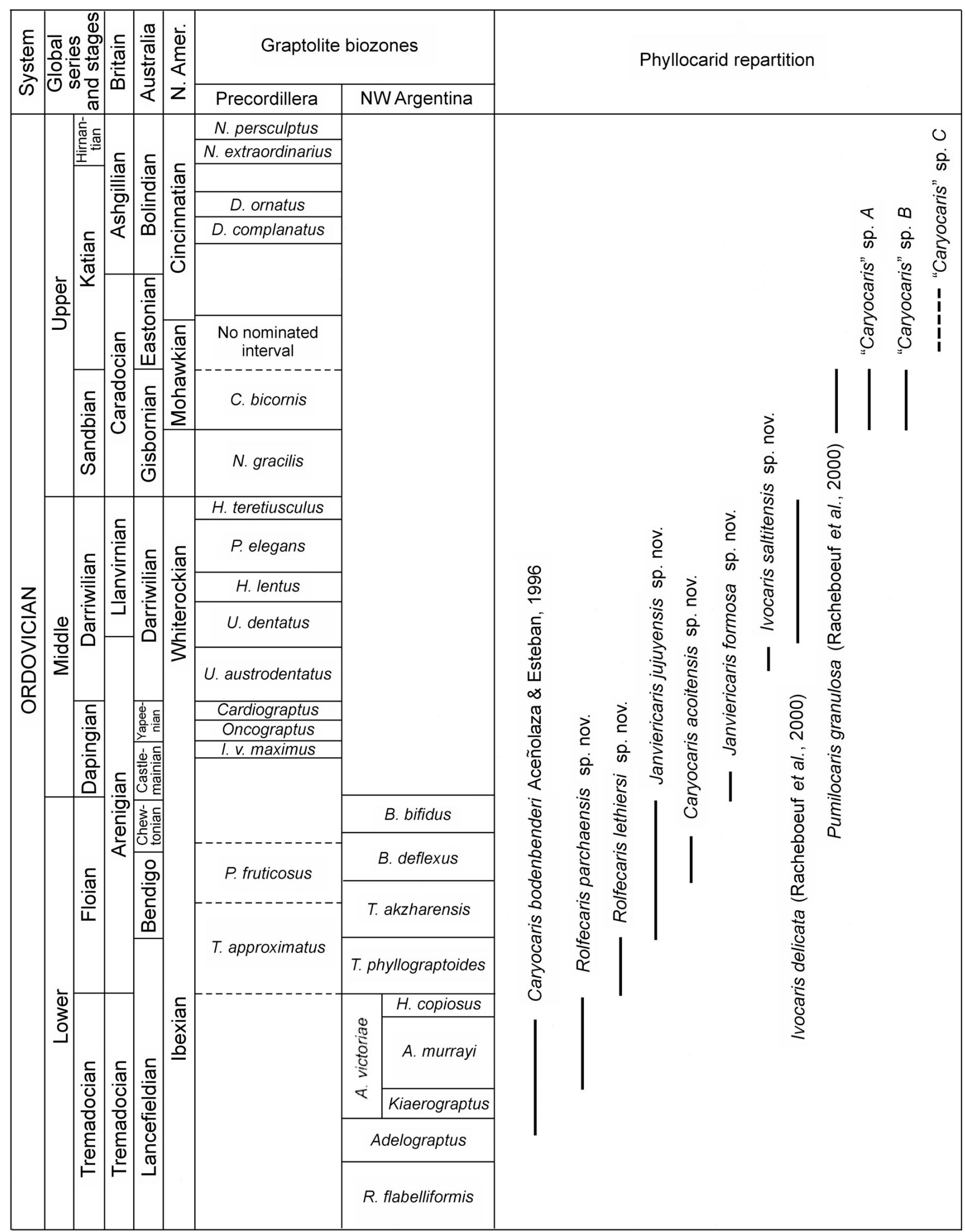

Figure 2. Biostratigraphy and graptolite zonation of the South American Ordovician and vertical range of the phyllocarid taxa from Argentina and Bolivia described in this paper. 
Formation (Astini 1994, 2003; Brussa et al. 2003b; Ortega \& Rickards 2003) is diachronous across the basin. In localities such as Cerro Viejo and Los Saltitos Creek the change is locally expressed as a sharp boundary. Phyllocarids come from both sections. The Gualcamayo Formation in Los Saltitos Creek is $12 \mathrm{~m}$ thick and comprises the Middle Member of this unit (sensu Astini 1994). The Undulograptus austrodentatus Zone (Undulograptus sinicus Zone) (Darriwilian/Da1) was recognized in these levels (Brussa \& Astini 1996, Brussa \& Flores in press), associated with specimens of Ivocaris saltitensis sp. nov.

Phyllocarids are also present in the Trapiche Group, the siliciclastic succession deposited above the Gualcamayo Formation. The Trapiche Group is composed of the Las Vacas Formation $(330 \mathrm{~m})$ and the Trapiche Formation (more than $800 \mathrm{~m}$ ). The Las Vacas Formation is a conglomeratic unit with varying facies. Several wedges of fine-grained graptolite-rich silty shales with lenses of fossiliferous limestones (former Las Plantas Formation) are present within this coarse grained interval, reflecting relatively warm climates (Astini 2003). Pumilocaris granulosa Racheboeuf, Vannier \& Ortega, 2000 is reported from equivalent levels in Cerro Potrerillo. The overlying Trapiche Formation is largely rhythmic with similar proportions of graded sandy beds embedded within black, silty shales and distinctive intercalations of amalgamated thick, sandy, lenticular units and limestone-clast dominated megabeds (Astini 1994, 2003). Only one specimen related to 'Caryocaris' sp. was reported from this unit in the Quebrada Zanja Honda Creek in the northern Precordillera.

\section{Environmental setting and preservation}

According to the literature, Ordovician representatives of the Subclass Phyllocarida mainly belong to the Family Caryocarididae and are, as a whole, considered to have been cosmopolitan members of the active epipelagic zooplankton (Vannier et al. 2003). Caryocaridid phyllocarids are mostly found associated with graptolites, in the graptolitic shale facies communities of the pelagic realm and the open-shelf environment, the Benthic Assemblage 6 of Boucot's (1975) classification. They were probably active swimmers (Vannier et al. 1997) living near the mesopelagic-epipelagic boundaries (Vannier et al. 2003), or in the uppermost part of the water column, in the upper photic zone, most probably associated with carpets of floating algal thalli (Chlupáč 2003).

The recent discovery of caryocaridids in the Upper Ordovician Soom Shale Lagerstätte of South Africa (Whittle et al. 2007) sheds new light on the family and to their environment. Firstly, the description of Caryocaris cedarbergensis Whittle et al. extends the distribution of the family up to the Ashgill, i.e., 10My more than previously established. Secondly, from an environmental point of view, the species is associated with many nektic and nektobenthic organisms, without any graptolite. Whittle et al. (2007) concluded that Caryocaris was "...a cool-adapted, stenothermic, mesopelagic group during the Early-Middle Ordovician [according to the wide distribution of the genus] and inhabited an epipelagic cold-water shelf environment during the Late Ordovician" (Whittle et al. 2007, p. 395). Such an hypothetical environmental shift from mesopelagic to epipelagic and from cool- to cold-water setting, through Ordovician times, can only be considered if we agree that caryocaridids belong to a single genus, namely Caryocaris, which is not the case, Caryocaris being considered to be a comprehensive genus.

Commonly abundant in the Ordovician black shale graptolitic facies, phyllocarid remains are unfortunately often poorly preserved. Their preservation is directly related to the small-sized, thin, flimsy nature and poorly mineralized composition of the exoskeleton. The flimsy nature of the exoskeleton is indirectly expressed by the scarcity of complete, articulated specimens, as well as by the coiling of carapaces, a post-mortem natural alteration tendency of the exoskeleton (Ekström 1937, Churkin 1966, Chlupáč 1970, Racheboeuf et al. 2000). The coiling of the carapace might have occured on the sea floor or, more probably, during their post-mortem fall to the sea floor. Preservation of caryocaridids might also have been affected by their excessive abundance, when carapaces and other exoskeletal parts are accumulated by currents on bedding planes. Poor preservation may also often result from diagenetic and metamorphic processes, or tectonics. The former induced flattening, alteration and/or destruction of the carapace, including mineralization processes, while the latter implied flattening, distortion, stretching etc. No example of coiling could be observed among archaeostracan remains assigned to the Family Ceratiocarididae, but it is to be noted that: 1) they are much less abundant than caryocaridids; 2) this fact may reflect a thicker, more mineralized cuticle, associated with a distinct mode of life, or both associated conditions.

Thousands of isolated elements of caryocaridid exoskeleton have been collected from the South American Ordovician sequence but most of them are very poorly preserved and, in some cases, up to about 200 isolated carapace valves and/or furcal rami have been counted on a single black shale bedding plane about $50 \mathrm{~cm}$ by $50 \mathrm{~cm}$ square. No complete exoskeleton has been found, the most complete specimens being articulated fragments of the abdomen. Only specimens retained in most competent levels, and those preserved in lenses and/or in early diagenetic concretions as in the Ordovician of Bohemia (Chlupác 1970) and in South America (this paper) are sufficiently well preserved to allow complete detailed descriptions. In 
addition, the low number of well preserved specimens preclude any biometric analysis as was carried out on the carapaces of the Bohemian material of Caryocaris wrighti and C. subula by Chlupáč (1970) for example. Measurements are given below for the best preserved carapaces only and for furcal rami, when reliable.

\section{Taxonomically significant characters in caryocaridids}

The anatomy of archaeostracan Crustacea is known from a few, exceptionally well-preserved specimens such as Nahecaris stuertzi Jaeckel, 1921 from the Lower Devonian Hunsrück Lagerstätte of Germany, Ceratiocaris papilio Salter, 1859, from the Silurian of Scotland (Rolfe 1962) and Ceratiocaris papilio and C. macroura from the Silurian of Ontario, Canada (Collette \& Rudkin in press). Other complete exoskeletons, although yet undescribed, are known from the Middle Ordovician Black Shales of Oklahoma (Hannibal \& Feldmann 1997), but such specimens remain exceptional. The only available information upon the segmentation of the pereion of caryocaridids was given by Hannibal \& Feldmann (1996) who figured a carapace of Caryocaris sp. from southern Bolivia showing indications of segmentation and the mandible in situ. However that interpretation is not fully convincing and remains questionable pending further observations.

The exoskeleton of caryocaridids (Fig. 3) resembles Recent phyllocarids such as Nebalia or Nebaliopsis. However, the bauplan of modern phyllocarids with its 5-8-7 segmentation pattern ( 5 head segments, 8 thoracic segments, 7 abdominal segments + telson) remains poorly known in caryocaridids, as in most archaeostracan phyllocarids, although it is globally accepted in the literature. Moreover, taxonomically significant characters in modern phyllocarids mainly relie upon features such as: the segmentation of antennule and antenna, morphology and structure of the eye stalk, morphology of thoracopods, etc. (see Rolfe 1969, pp. R312-314), i.e. characters which are only exceptionally preserved in fossil specimens. This fact implies that the taxonomy of Paleozoic phyllocarids, among which are the caryocaridids, relies mainly upon morphologic characters of exoskeletal elements (carapace, abdominal somites, tail piece).

Representatives of the genus Caryocaris share a relatively small-sized carapace (less than $50 \mathrm{~mm}$ long; commonly about 20 to $30 \mathrm{~mm}$ ) and all are characterized by a thin, bivalved, elongated carapace. Both valves were most probably articulated along the dorsal hingeline by transverse muscles and ligaments, without any articulatory process. The carapace is devoid of rostral and median dorsal plates, in contrast with most other
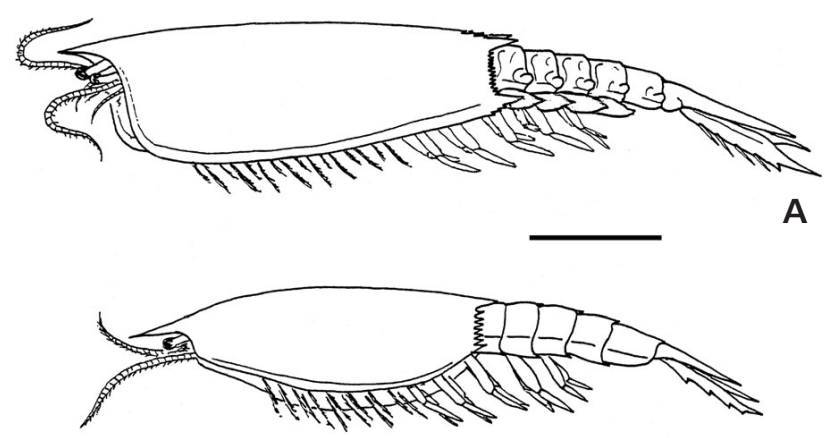

B

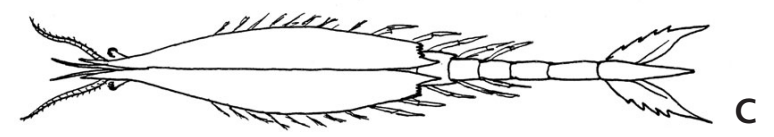

Figure 3. Tentative reconstructions of the complete exoskeleton of caryocaridids. - A - Janviericaris formosa gen. et sp. nov., in lateral view. - B, C-Caryocaris acoitensis sp. nov., in lateral and dorsal views, respectively. Scale bar is about $10 \mathrm{~mm}$.

Archaeostraca (Rolfe 1969, Vannier et al. 1997). Most species of Caryocaris exhibit a variably developed anterior horn, which is an anterior expansion of each carapace valve. The relative development of the anterior horn led to the distinction of the subgenera $C$. (Caryocaris) with a short horn, and C. (Rhinopterocaris) with a long horn (Chlupáč 1970). However, the variable morphology and development of that character makes it unreliable, even at the subgenus level and led to the suggestion that the latter subgenus is a junior synonym of the former (Racheboeuf et al. 2000, Chlupáč 2003). If we consider Caryocaris zhejiangensis Shen, 1986, the curvature of the anterior horn may result from deformation. Ventrally, the carapace of caryocaridids exhibits a narrow, flattened ventral border which is limited by a shallow furrow. The inner side of the carapace bears a well defined doublure as could be established from well preserved specimens from southern Bolivia (Fig. 4).

The carapace of caryocaridids usually exhibits a variably spinose posterior margin. If the posterodorsal spine is usually present, the posteroventral one may be variably developed, reduced or lacking. The posterior margin is commonly straight, or variably sinuous and nearly vertical. In some cases it may be obliquely oriented, especially when the posteroventral spine is shortened, as in Caryocaris subula Chlupáč, 1970 and even more so when the posteroventral spine is absent as in $C$. delicata Racheboeuf et al. 2000. The posterior parts of the ventral and dorsal margins may bear (both or neither) a variable number of short, posteriorly directed, spinose expansions named here 'pre-posteroventral' and 'pre-posterodorsal' spines, respectively (see Fig. 4). An exception is C. cedarbergensis which has a smooth posterior margin and ventral border extending backward to almost the short posterodorsal 

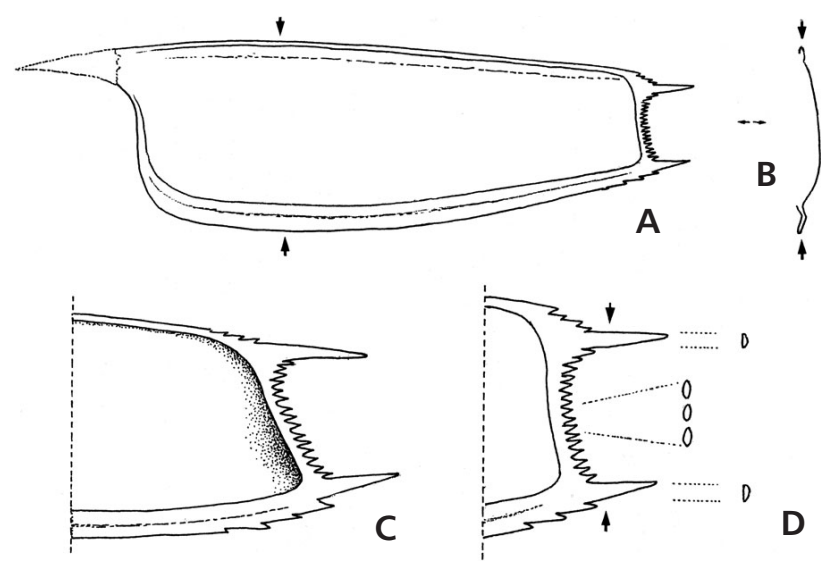

Figure 4. Janviericaris formosa sp. nov. Reconstructed inner side of a right valve showing the outline of the inner border (A) with the corresponding cross section (B); arrows indicate the location of the cross section. $\cdot \mathrm{C}$-hypothetical anteroventral view of the inner posterior part of the carapace. $\bullet \mathrm{D}$ - enlarged view of the posterior margin of the carapace with cross sections of spines; note the elliptical section of the small posterior spines and the sub-semicircular cross section of posteroventral and posterodorsal spines. Pre-posteroventral and pre-posterodorsal spines are well developed.
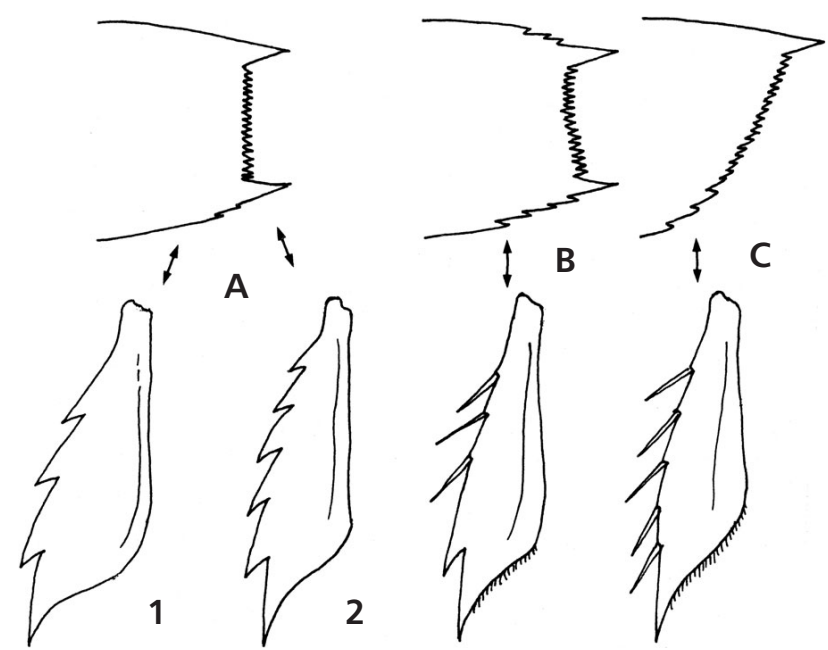

Figure 5. Compared morphology and outline of the posterior margin of the carapace (above), and of the corresponding furcal rami (below) for the three caryocaridid genera discussed in this paper. $\bullet \mathrm{A}-$ Caryocaris Salter, 1863 (A1 - C. bodenbenderi, A2 - C. acoitensis). $\bullet$ B - Janviericaris gen. nov. $・ \mathrm{C}-$ Ivocaris gen. nov.

spine. The discovery of almost three-dimensionally, well preserved, caryocaridid specimens in early diagenetic concretions and lenses of southern Bolivia (Chapiuno section, north-west of Tarija), completes our knowledge of exoskeleton morphology. A doublure was previously known to strengthen the ventral margin of the carapace (Vannier et al. 1997, 2003); the preservation of the newly collected Bolivian specimens allows study of the precise development of the doublure, especially in the posterior part of the carapace.
When developed, posterodorsal and posteroventral spines are not only leaf-like expansions of the dorsal and ventral margins. They are hollow with a markedly convex external side and a flat inner side, giving them a typical subsemicircular cross section. Secondary spinules, developed between these two spines, along the posterior margin of the carapace, are also three-dimensionally preserved and exhibit a subelliptical cross section. The hollow nature of spines and spinules is attested by the sediment infilling. As a consequence, the posterior part of the carapace was also underlined by a doublure, like the dorsal and ventral margins (Fig. 4).

The pleon is still poorly known. Complete exoskeletons are rare and abdominal elements (pleonites) of the exoskeleton are most often found as isolated segments, or still connected together and/or connected to the tail piece. As can be understood from the completely preserved specimens, five of the seven pleonites are exposed beyond the posterior margin of the carapace. In this way the reconstruction of the complete exoskeleton is somewhat different (Fig. 3) from that proposed earlier (Vannier et al. 2003, fig. 2A, B, p. 176). All pleonites are about the same length and they become less elevated and narrower posteriorly. The last, pretelson pleonite, is sometimes more weakly elongated than the preceding ones. According to the species, each pleonite may bear short dorsal posterodorsal spines and their flanks may exhibit a lateral longitudinal carina, as in Caryocaris. In Caryocaris acoitensis sp. nov., pleonites lack posterodorsal spines and the short lateral carina ends in a small posterior rounded tubercle.

The tailpiece includes the telson and a pair of furcal rami. The telson is typically triangular in outline, with weakly convex lateral margins and a pointed posterior end. It is weakly concavoconvex in cross section, its ventral side being flat to weakly concave. Furcal rami are most often elongated, typically leaf-like or, more precisely, flame-like in outline, with a pointed extremity (Fig. 5), the only exception being Caryocaris stewarti Jell, 1980 which exhibits widened, subtriangular furcal rami. These flattened natatorial organs, are articulated below the head of the telson, with a small, rounded articulatory process. Their inner margin is almost straight in its anterior half, becoming variably convex backwards, then concave to join the posterior acute extremity. When well-preserved, the posterior, concave part of the inner margin of furcal rami commonly bears a row of very small spinules. The outer margin of the rami is weakly to markedly convex. In Caryocaris, it bears a variable number (usually 3 to 6) of flattened, triangular, spine-like expansions (Fig. 5A1, 2); in other forms, such as Janviericaris gen. nov. only the most posterior triangular expansion is still present and the others are replaced by small articulated spinules (Fig. 5B), anterior lateral spine-like expansions; in Ivocaris gen. nov. all lateral ex- 
pansions are replaced by small articulated spinules (Fig. 5C); based on such observations, the assignment of the species C. stewarti Jell, 1980 to the genus Caryocaris seems questionable.

Phyllocarid carapaces yielded from black shales can be only superficially appreciated or evaluated in size and outline, because of diagenetic and/or tectonic processes. Although the anterior margin of the carapace appears to be possibly significant from a taxonomic point of view [relative development of an anterior horn or not; see Caryocaris (Rhinopterocaris) Chlupáč, 1970; curvature of the anteroventral part of the carapace, etc.], the most reliable feature on the carapace seems to be the morphology and ornamentation of its posterior margin: 1) smooth or spinose ventro- and dorsoposterior margins; 2) presence or absence, and relative development of ventro- and dorsoposterior spines; 3 ) number and relative development of secondary spines (spinules) along the posterior margin of the carapace between the posterior spine(s), and 4) outline and orientation of the posterior margin of the carapace (vertical, oblique, straight or sinuous, etc.).

As complete exoskeletons, with abdominal segments and tail piece still connected are rarely preserved, other reliable characters and features are connected with the tail-piece, i.e., the telson and furcal rami. In Caryocaris, the telson most often looks like a triangular, transversally concavoconvex, pointed element of the exoskeleton, with or without longitudinal lateral ridges or furrows. Due to diagenetic compaction and/or tectonic distorsion, its concavoconvex lateral profile, its length-width ratio is of no value, excepted when three-dimensionally preserved in early diagenetic concretions. Furcal rami are considered here, together with the posterior margin of the carapace, to be highly significant at the genus and species taxonomic level. Due to their flattened, leaf-like morphology, furcal rami can only be affected by tectonic distorsion which would only affect their length-width ratio. Tectonics would not affect the presence (or the lack) of leaf-like spinose expansions on their lateral outer margin, as well as that of articulated spines, or that of small spinules on their inner, convex, posterior margin. Regarding furcal rami we consider the following characters to be taxonomically significant: 1) the morphology and outline; 2) the presence (and number) or absence of spine-like expansions along the outer margin; 3) the presence or absence of long and narrow, acute, articulated (or non-articulated) spines; 4) the presence of setae along the posterior margin. However, the length ratio between the telson and the two flat furcal rami may be relevant. On the base of such considerations, we consider here that the Family Caryocarididae as it was originally proposed by Racheboeuf et al. (2000), can no longer be assigned to the Suborder Ceratiocaridina.

\section{Systematic palaeontology}

Class Malacostraca Latreille, 1806

Subclass Phyllocarida Packard, 1879

Order Achaeostraca Claus, 1888

Family Caryocarididae Racheboeuf, Vannier \& Ortega, 2000

[non Caryocaridae Chapman, 1903].

Diagnosis. - Small to medium-sized, elongated, bivalved carapace covering thoracic and anterior abdominal pleonites, lacking prominent nodes and ridges, devoid of rostral and median dorsal plates; anterior horn variably developed; posterior margin straight, oblique or sinuous usually spinose, with variably developed posterodorsal and posteroventral spines; posteroventral spine sometimes reduced or absent; abdominal pleonites short with pretelson somite about the same length; tail piece with triangular telson and a pair of furcal rami.

Genera assigned. - Caryocaris Salter, 1863; Janviericaris gen. nov.; Ivocaris gen. nov.

Remarks. - The family Caryocaridae (sic) was firstly proposed by Chapman (1903, p. 113) but this author did not give any diagnosis of the new family which included the genera Caryocaris, Saccocaris Salter, 1873, and the new genus Rhinopterocaris. Rolfe (1969, p. R315) considered the family Caryocaridae Chapman, 1903, as a junior synonym of the family Ceratiocarididae Salter, 1860 in which he placed Caryocaris together with the genera Ceratiocaris M'Coy, 1849 (?Early Ordovician to ?Late Permian), Gonatocaris Gürich, 1929 (Late Silurian) and Heroldina Broili, 1931 (Lower Devonian) (Rolfe 1969, p. R315-317). The exoskeleton of Caryocaris exhibits such a range of peculiar characters that it can no longer be assigned to the family Ceratiocarididae Salter, 1860 . Hence the family Caryocarididae was proposed by Racheboeuf et al. (2000) to accomodate the single genus Caryocaris, the genus Rhinopterocaris Chapman, 1903 being considered to be a synonym of Caryocaris (Racheboeuf et al. 2000) and Saccocaris questionably belonging to the phyllocarids (Rolfe 1969, p. R327). According to the diversity of morphological characters related to time, as expressed in this paper, it clearly appears that the genus Caryocaris, as up to now accepted, is a comprehensive taxon. Such an idea was recently supported by Chlupáč (2003). The diagnosis of the family Caryocarididae is accordingly emended above to accomodate the two new genera together with Caryocaris.

\section{Genus Caryocaris Salter, 1863}

Type species. - Caryocaris wrightii Salter, 1863. 
Junior synonyms. - Caryocaris (Rhinopterocaris) Chlupáč, 1970; Dawsonia Nicholson, 1873 (pars; see Page et $a l$. in press).

Emended diagnosis. - Caryocaridids with posterior margin of carapace valve almost subvertical, straight, with welldeveloped posterodorsal and posteroventral spines and with a row of variably developed tiny spines; variable number of subtriangular, flattened, spine-like expansions along the outer lateral margin of leaf-like furcal rami.

Species assigned. - Caryocaris wrightii Salter, 1863 (type species); Caryocaris wrighti Salter, 1863, sensu Chlupáč 1970; Caryocaris wrighti sensu Rushton \& Williams 1996; Caryocaris acuminata (Nicholson, 1873); Caryocaris bodenbenderi Aceñolaza \& Esteban, 1996; Caryocaris acoitensis sp. nov.

The species C. stewarti Jell, 1980 is provisionally left within the genus Caryocaris.

Geographic distribution. - England, Ireland, Belgium, Germany, Czech Republic, Canada, United States, Argentina, Bolivia, Colombia, Peru.

Stratigraphic range. - Tremadocian-Floian (lower Arenig).

Remarks. - The type species of Caryocaris, C. wrightii, was initially described from a single carapace from the Arenig strata of the Skiddaw Group of England (Salter 1863, p. 139). The tail piece remained unknown until Chlupáč (1970) described specimens from the Darriwilian Šárka and Dobrotivá formations of Bohemia which he assigned to Salter's species. More recently Rushton \& Williams (1996) described the tail piece of $C$. wrightii from the Hope Beck and Kirkstile formations of the Skiddaw Group, in the supposed type area of England and from the Oaklands Fm. of Ireland and compared their material with the Bohemian specimens of $C$. wrightii described and reconstructed by Chlupáč (1970). However, two points needs to be emphasized and discussed:

- According to Rushton \& Williams (1996), it clearly appears that both the British and Irish furcal rami bear outer lateral, spine-like flattened expansions ('spinules' of the authors), but whilst the oldest British specimen (varicosus Biozone) bears 5 expansions, the youngest specimens (gibberulus and hirundo Biozones) bear only 3 expansions (op. cit., p. 108). The question is: 1) do the two morphotypes really belong to the same species?; 2) if not, does the type species $C$. wrightii bear 5 or 3 lateral spinelike expansions?

- Rushton \& Williams (1996) noted (p. 108) that the Bohemian specimens assigned by Chlupáč to $C$. wrightii show "... only one distinct spinule [= spine-like flattened expansion] towards the rear end of the outer lateral margin, in front of which ... 3-4 tiny notches, suggestive of the presence of further minute spinules". However, the authors did not discuss the significance of these characters. Original specimens of C. wrighti - sensu Chlupáč 1963 - have been carefully observed by Dr. P. Budil (Geological Survey, Prague) who is greatly acknowledged here. According to photos it is unclear whether the 'tiny notches' correspond to the articulatory processes of very small moveable spines and in this respect they cannot be compared with lateral spine-like expansions, or to the bases of very minute, elongate spines almost parallel to the outer margin of the furcal rami. Thus they can no longer be compared with lateral spine-like expansions either. Taxonomically, this last character means that, in our opinion, the Bohemian specimens can no longer be assigned to the species $C$. wrightii Salter, 1863, nor to the genus Caryocaris. Bohemian specimens (tail pieces and furcal rami) of $C$. wrighti figured by Chlupáč are probably more closely allied with $C$. subula Chlupáč, 1963. Chlupáč wrote (1970, p. 58) that both species occur together in the Llanvirnian beds of the Šárka Fm. Moreover the specimen ICh 781 of $C$. wrighti figured by Chlupáč on plate 1, fig. 9, exhibits a posterior margin of the carapace which looks different from the posterior margin of valves illustrated on plate 2 . The first specimen would probably (?) be better assigned to Ivocaris gen. nov., while specimens figured on plate 2 resemble Janviericaris gen. nov.

Within the family Caryocarididae we consider the genus Caryocaris to be characterized by the presence of lateral, subtriangular, spine-like flattened expansions along the outer lateral margin of elongated, leaf-like furcal rami and the diagnosis of the genus Caryocaris is emended accordingly. In other respects here we follow Chlupáč's remarks (2003, p. 107) about the feminine gender of the Greek word karys (= shrimp) implying species name endings in ' $-a$ ' instead of '- $u s$ ' (Article 34 of the ICZN).

\section{Caryocaris bodenbenderi Aceñolaza \& Esteban, 1996} Figure 6A-C

1996 Caryocaris bodenbenderi; Aceñolaza \& Esteban, p. 283.

2000 Caryocaris bodenbenderi. - Racheboeuf, Vannier \& Ortega, pp. 318, 326.

2004 Caryocaris bodenbenderi. - Racheboeuf, pp. 258, 260.

Type locality. - Quebrada del Portezuelo de la Alumbrera (Cuesta de Miranda), Provincia de La Rioja, Argentina.

Material and occurrence. - Eight specimens No. PIL 14182 (holotype) and PIL 14183 to 14189 (paratypes) originally designated by the authors, from the late Tremado- 
cian deposits of the Bordo Atravesado Formation, Sierra de Famatina.

Remarks. - As previously established, the phyllocarid remains upon which the species $C$. bodenbenderi was defined, are furcal rami and not carapaces (Racheboeuf et al. 2000, pp. $318,326)$. The original material is redescribed below.

Description. - Carapace unknown. Length of furcal rami between about $5 \mathrm{~mm}$ and $10.3 \mathrm{~mm}$ long (measurements from the 5 more complete specimens); corresponding length : width ratio between 2.37 and 3.50 , but most specimens are broken in their proximal part, or weakly distorted. The holotype, which is the largest and more complete specimen, is $10.26 \mathrm{~mm}$ long and $2.93 \mathrm{~mm}$ wide, with a $\mathrm{L}: \mathrm{W}$ ratio of 3.50. The maximum width of the ramus is located in the posterior third of the total length. The outer margin of the furcal ramus is moderately to markedly, regularly convex. It bears two to three relatively large, triangular, flattened and posteriorly directed spine-like outgrowths. The anterior spine-like outgrowth is often much smaller than posterior ones and sometimes scarcely perceptible, probably due to preservation. The inner margin is almost straight or weakly concave in its anterior half, becoming strongly convex up to the inner base of the terminal spine. The pointed, terminal spine is relatively large and stout. The distal inner margin shows no spinules or setae. A shallow longitudinal furrow originating from the condyle, reaches the inner margin of the terminal spine.

Discussion. - Due to the misinterpretation of furcal rami as carapaces, as previously stated (Racheboeuf et al. 2000), the authors compared $C$. bodenbenderi with several taxa exhibiting a well-developed anterior horn. However, regarding the characters of the furcal rami, $C$. bodenbenderi can only be compared with species that exhibit several spine-like, flattened, outgrowths along the outer margin, such as C. wrighti Salter, 1863, sensu Rushton \& Williams (1996), and other species of Caryocaris sensu stricto.

The furcal rami of $C$. bodenbenderi differ markedly from those of $C$. wrightii Salter (the type species) and other species of the genus Caryocaris by a less elongate outline, with a strongly convex, almost geniculate interior margin and a convex outer margin bearing two to three spine-like outgrowths instead of five. The terminal spine is also stouterand better differentiated in $C$. bodenbenderi.

\section{Caryocaris acoitensis sp. nov.}

Figures 3B, C, 6D-H

2000 Caryocaris sp. 1; Racheboeuf, Vannier \& Ortega, p. 328.

2004 Caryocaris sp. 1. - Racheboeuf, p. 260.

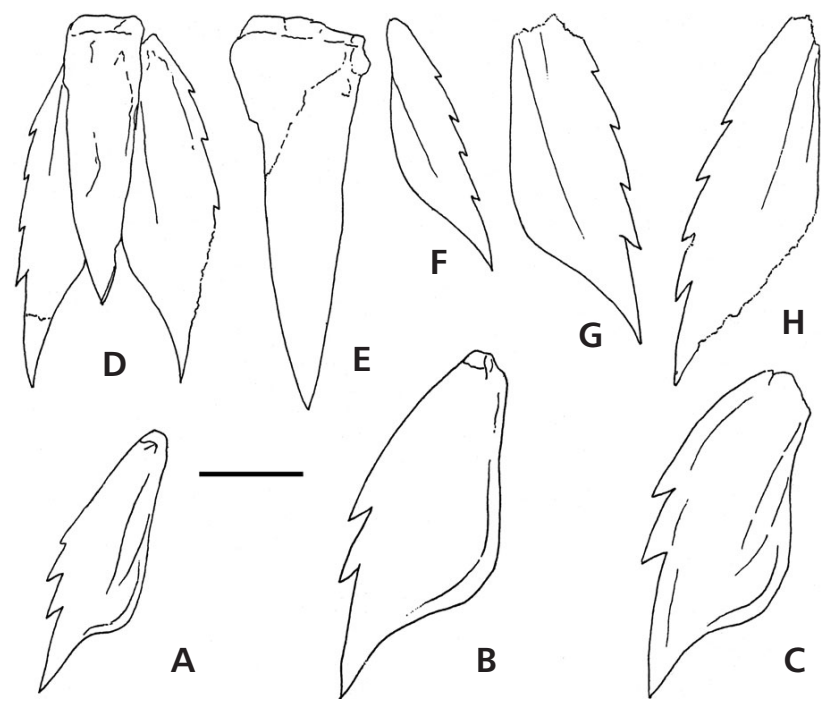

Figure 6. Camera lucida drawings. Furcal rami, all $\times 8$. $\bullet \mathrm{A}-\mathrm{C}-\mathrm{Ca}$ ryocaris bodenbenderi Aceñolaza \& Esteban, 1996. Locality Quebrada del Portezuelo de la Alumbrera, Provincia de La Rioja, Bordo Atravesado Formation, Tremadoc. A - holotype, No. PIL 14182. B - No. PIL 14188. C - No. PIL 14189. • D-H - Caryocaris acoitensis sp. nov. Mina Natasia section, locality 2, Acoite Formation, Arenig. D - tail piece, holotype, No. 23319. E - isolated telson, No. 23323. F-H - furcal rami, No. 23320 to 23.322 respectively. Scale bar $=2 \mathrm{~mm}$.

Holotype. - Tail piece No. 23319, telson with the two furcal rami still connected (Fig. 6D).

Etymology. - From the Acoite Fm., the stratum typicum.

Type locality. - Section along the trackway between road 52 and Mina Natasia, locality 2, sampled in 2000, about 1

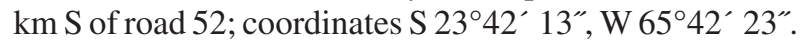

Material and occurrence. - A complete tail piece, an isolated telson and ten isolated furcal rami, among which five well-preserved specimens (No. 23319 to 23323). Argentina, Eastern Cordillera, Acoite Formation, level possibly equivalent to the Baltograptus deflexus Zone (upper Be2 to $\mathrm{Be} 4)$, middle to late Floian.

Diagnosis. - Species characterized by relatively wide furcal rami with a markedly but regularly convex outer margin with four flattened spine-like outgrowths; inner margin markedly convex at three quarters of the furca length from the anterior extremity.

Description. - Telson subtriangular, elongated in outline, with posterolateral margins weakly convex, ending in stout posterior spine. The largest telson (Fig. 6E) is $7.5 \mathrm{~mm}$ long with a corresponding width of $2.75 \mathrm{~mm}$, i.e. a length : width ratio of 2.72. Telson head with a weak, transverse furrow terminating laterally at the anterior margin of the rounded articulatory process. The largest 
furcal ramus is $7.4 \mathrm{~mm}$ long with a corresponding width of $2.5 \mathrm{~mm}$. The length : width ratio of the furcal rami is about 3 (between 3 and 3.17; 4 measurements). The outer margin is regularly convex and bears four flattened, regularly spaced, spine-like outgrowths the size of which weakly increases posteriorly. Inner margin almost straight in its anterior half, becoming markedly convex, then bending outwards to delineate the wide and curved terminal spine. Each furcal ramus bears a weak longitudinal furrow almost parallel to its longitudinal axis. No setae could be observed along the inner posterior margin of the available material.

Discussion. - At first sight, the furcal rami of $C$. acoitensis sp. nov. resemble that of $C$. bodenbenderi Aceñolaza \& Esteban, 1996, but they can be easily distinguished by their more elongated outline, i.e., a higher length : width ratio between 3.5 and 4, instead of 2.37 to 3.5 in C. bodenbenderi. In C. acoitensis sp. nov. the inner margin of the furcal rami is much less convex, less arcuated than in $C$. bodenbenderi and the spine-like expansions number four along the outer margin, instead of two to three and all expansions are about the same size. The furcal rami of $C$. acoitensis sp. nov. differ from $C$. wrightii as illustrated by Rushton \& Williams (1996, Fig. 2) by both the better differentiated and relatively longer terminal spine and the outline of the spine-like outgrowths which are more triangularand more prominent along the outer margin. Considering the number of spine-like outgrowths, specimens of $C$. wrightii from the varicosus Zone exhibit five 'spinules' while those from the gibberulus-hirundo Biozones bear 3 spinules. C. acoitensis sp. nov. from the deflexus zone bears four spine-like outgrowths.

\section{Genus Janviericaris gen. nov.}

Type species. - Janviericaris formosa sp. nov.

Etymology. - To honour Dr. Philippe Janvier, MNHN, Paris, for his work on South American Paleozoic vertebrates.

Diagnosis. - Caryocaridids with an almost vertical anterior margin below the short anterior horn; subvertical, sinuous spinose posterior margin of the carapace; well-developed posterodorsal and posteroventral spines; pre-posteroventral and pre-posterodorsal spines usually developed; furcal rami with a unique spine-like expansion and small articulated anterior spines.

Comparison. - Janviericaris gen. nov. differs primarily from Caryocaris by the variably sinuous posterior spinose margin of the carapace. Moreover, the posterior end of the dorsal line, just before the posterodorsal spine, is usually arcuated, more or less convex dorsally, with several preposterodorsal spine-like expansions. The outer margin of the furcal rami bears a unique, posterior, flattened spinelike expansion and anteriorly small articulated spines inserted on notches, instead of three to five spine-like expansions.

Species assigned. - Janviericaris formosa sp. nov. (type species); J. jujuyensis sp. nov.; ?Caryocaris monodon Gurley, 1896; C. curvilata Gurley, 1896.

Geographic distribution. - Southern Bolivia and northwestern Argentina; North America.

Stratigraphic range. - Floian-Darriwilian.

Janviericaris formosa sp. nov.

Figures 3A, 4, 5B, 7, 8

1965 Caryocaris sp. - Branisa, p. 12.

1965 Ceratiocaris sp. - Branisa, pp. 76, 227, 228, pl. 6, fig. 6.

2000 Caryocaris. - Legrand, Smith \& Hannibal, pp. 12, 13.

2003 Caryocaris sp. 3. - Vannier et al., fig. 6 (pars).

2004 Caryocaris sp. 1. - Racheboeuf, fig. 25.1 (pars).

Etymology. - From the Latin formosus, - a: fine, beautiful, elegant.

Holotype. - Right valve of the carapace, MNHNC13330 (Fig. 8A-C).

Type locality. - Quebrada Chapiuno section, along the road Iscayachi-Culpina, $61.9 \mathrm{~km} \mathrm{NW}$ of Tarija and about $14 \mathrm{~km}$

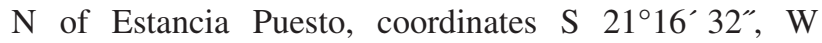
$65^{\circ} 10^{\prime} 57^{\prime \prime}$, Department of Tarija, Province of Méndez, southern Bolivia. Azygograptus lapworthi Zone, equivalent to the Pseudophyllograptus angustifolius Zone of Baltoscandia, equivalent to the Castlemainian Cal of Australia, middle Arenig, Dapingian.

Material and occurrence. - 76 more or less complete carapaces, 5 tail pieces, 2 telsons and 13 furcal rami have been collected from two silty lenses with cone in cone structures, at the top of the Ordovician sequence, about 60 meters below the Ordovician/Cretaceous unconformity. Pircancha/Cieneguillas formations, Azygograptus lapworthi Zone, Arenig (Third Stage). B. formosa sp. nov. also occurs in northernmost Argentina, in levels 4 to 11 of the Muñayoc section, W of Abra Pampa, Jujuy Province. Level 4 might be considered to be an equivalent of the Ch1 (Chewtonian), while levels 9 and 11 can be assigned to the Ch2 (they may possibly reach the Ca1 - Castlemanian) of Australia, middle Arenig (late Floian-early Dapingian). 

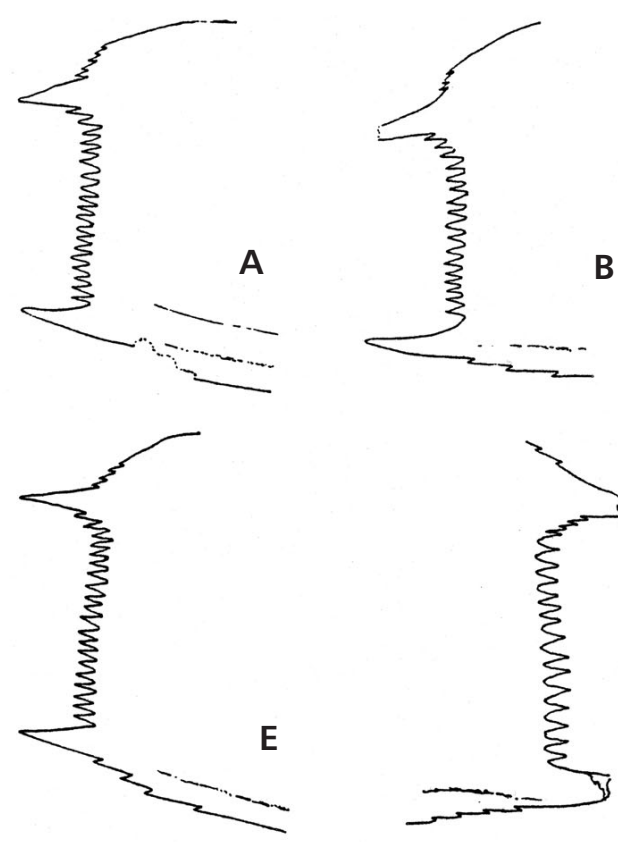

E
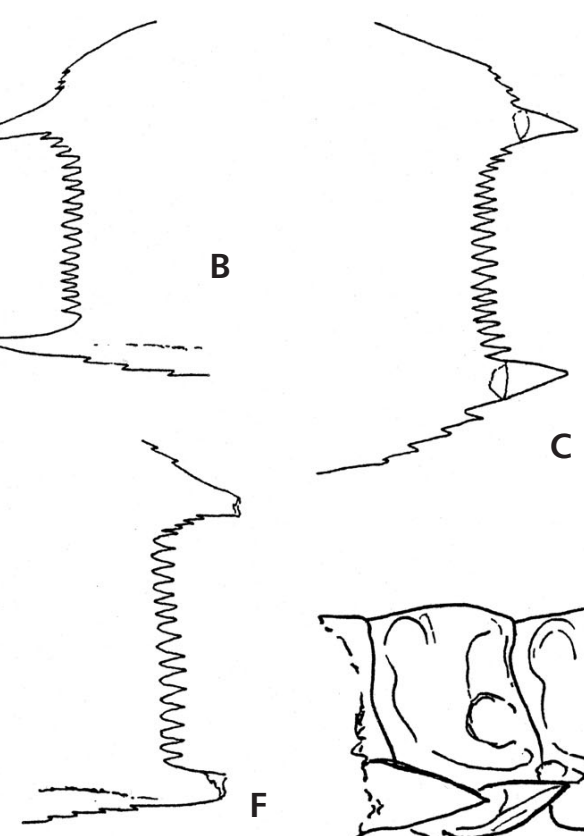

C
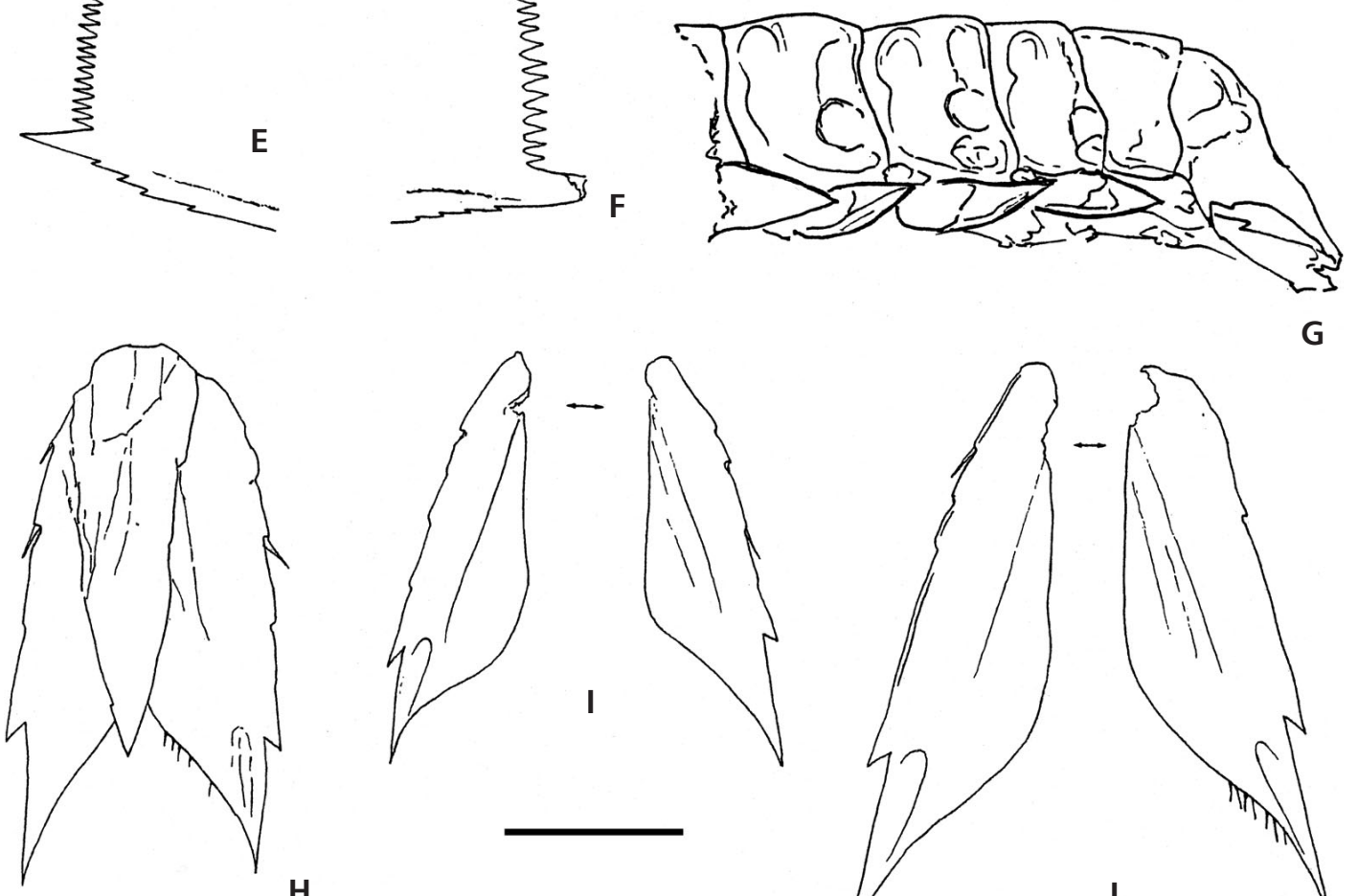

H

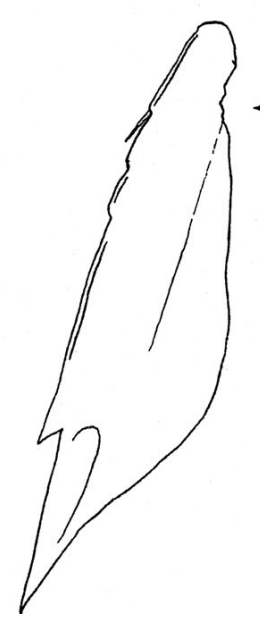

G

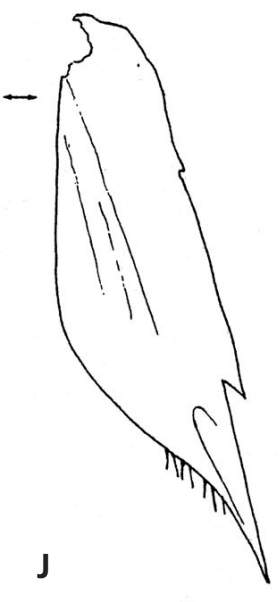

Figure 7. Janviericaris formosa sp. nov. Camera lucida drawings of specimens from the Chapiuno section, type locality, NW of Tarija, Southern Bolivia. - A-F - posterior part of several valves of the carapace showing the sinuous spinose margin; A - MNHNC 13334, B - MNHNC 13339, C-MNHNC 13340, D - MNHNC 13332, E-MNHNC 13341, F-MNHNC 13343. • G - five abdominal somites still connected with the tail piece, in lateral view, MNHNC 13342. $\bullet \mathrm{H}$ - tail piece, MNHNC 13335. • I, J - upper and lower sides of two isolated furcal rami MNHNC 13338 (I), and MNHNC $13344(\mathrm{~J})$. Scale bar $=5 \mathrm{~mm}$.

16 specimens (holotype and paratypes) are numbered MNHC 13330-13345.

Diagnosis. - Species of Janviericaris with markedly sinuous posterior margin of carapace; well-developed posterodorsal and posteroventral spines and pre-posterodorsal and pre-posteroventral short spines; 18 to 26 long, relatively stout posterior spinules, numbering 6 to 9 per mm.

Description. - Carapace: Maximum observed length about $28.0 \mathrm{~mm}$ for a corresponding height of $10.0 \mathrm{~mm}$. Carapace length : height ratio $(\mathrm{L}: \mathrm{H})$ between 2.63 and 2.97 for 8 carapaces between $12.5 \mathrm{~mm}$ and $28 \mathrm{~mm}$ long. However the species may reach a larger size, as in level 11 of the Muñayoc section where weakly tectonically distorted carapaces of $40 \mathrm{~mm}$ long are not uncommon. None of the available specimens have their anterior horn preserved, the anterodorsal part of the carapace always being irregularly broken (Figs 4A, 8D). However the broken line suggests a stout, relatively short horn. Dorsal line gently and evenly arched. Anteroventral margin markedly convex, with a very narrow but well developed marginal rim. Narrow ventral 
border (approx. $0.6 \mathrm{~mm}$ to $0.7 \mathrm{~mm}$ wide), subtriangular in cross section, dorsally limited by a well impressed ridge running parallel to the whole ventral margin which is evenly and regularly arched. Posterior part of the ventral margin bearing 4 to 6 small, short, and posteriorly directed, pre-posteroventral spine-like expansions. Posterior part of the dorsal margin weakly convex, bearing 4 to 5 very short, posteriorly directed, pre-posterodorsal spine-like expansions. Posterodorsal and posteroventral spines strongly developed, of the same size, up to $2.5 \mathrm{~mm}$ to $3.0 \mathrm{~mm}$ long, semicircular in cross section (Fig. 4D). Their outer side is regularly and markedly convex, while their inner side is flat. Posterior margin of the carapace weakly oblique and sinuous between the two posterior spines and bearing 18 to 26 posteriorly directed spinules. Spinules subelliptical in cross section, decreasing in width and length towards the posterodorsal spine. Length of spinules between $0.8 \mathrm{~mm}$ and $1.0 \mathrm{~mm}$.

Ornamentation of the carapace: Except for the bottom of the longitudinal dorsal and ventral furrows and the top of the ridges, as well as the dorsal and ventral margins, which are smooth, the carapace surface is extremely finely granulose (Fig. 8) and devoid of any other kind of ornamentation.

Abdominal somites: Some are preserved still in connection with the tail pieces, while others have been observed as isolated elements. Specimen No. 13342 (Fig. 7G) exhibits five pleonites in connection with the tail piece. The total length of the five somites equals $5.2 \mathrm{~mm}$ along their dorsal side, indicative of a mean length close to $1.0 \mathrm{~mm}$ per somite. Their height is about $2.5 \mathrm{~mm}$ but this is of little use as the abdomen is markedly flattened and compressed laterally.

Tail piece: Telson subtriangular, elongate, with straight lateral margins becoming very weakly convex near posterior extremity which ends in a very tiny, acute, short spine. Cross section concavoconvex. Dorsal side devoid of any ridge and/or furrow. Maximum observed length about $9.0 \mathrm{~mm}$ for a corresponding width of $2.4 \mathrm{~mm}$ near its proximal end; $\mathrm{L}$ : W ratio between 3.2 and 3.77 for five specimens. Furcal rami relatively elongated. Observed length between $4.65 \mathrm{~mm}$ and $11.0 \mathrm{~mm}$; corresponding width between $1.25 \mathrm{~mm}$ and $2.8 \mathrm{~mm}$ for 14 specimens. $\mathrm{L}$ : $\mathrm{W}$ ratio varying between 3.5 and 4.05. Maximum width located at about mid length. Outer lateral margin very weakly and evenly convex, with a unique, relatively small-sized, spine-like triangular expansion; base of the spine located between one quarter and one third of the total length from the long, narrow, spinose posterior extremity.

Anterior to the spine-like expansion, three very small spines are regularly spaced, inserted and articulated on notches. Inner margin almost straight in its proximal part, becoming regularly convex at about mid length, then be- coming concave terminating in a well differentiated terminal spine. Distal inner margin, between maximum width and terminal spine, fringed by numerous short setae. Each furcal ramus exhibiting a well differentiated longitudinal, submedian furrow originating anteriorly at the inner side of the articulatory process and ending at about two-thirds of the total length. A very discrete furrow, markedly arched in its antior part, running from almost the base of the spine-like expansion to the axis of the terminal posterior spine.

Comparison. - Among previously described species, $J$. formosa sp. nov. can only be compared with Caryocaris curvilata Gurley, 1896. The outline and morphology of the posterior part of the carapace of the North American species is very similar to that of $J$. formosa sp. nov. with pre-posterodorsal and pre-posteroventral short spines and a sinuous posterior margin. However, Gurley's species exhibits 13 to 15 posterior spinules between the two posterior spines, instead of 18 to 26 in J. formosa sp. nov. (Churkin 1966, Rolfe unpublished). These characters make the species curvilata a probable representative of Janviericaris gen. nov. According to Churkin (1966) C. curvilata is known from Alaska, Great Basin (USA) and Canada in beds of probable upper Floian-lower Dapingian age (Didymograptus hirundo or D. bifidus zones).

\section{Janviericaris jujuyensis sp. nov.} Figures 9A-L, 10A-ZD

Etymology. - From the Jujuy Province of northern Argentina.

Holotype. - Specimen No. 23295, posterior margin of both valves of a carapace (Fig. 9E).

Type locality. - Los Colorados section, Acoite Fm., W-NW of Purmamarca, Jujuy Province, northern Argentina.

Material and occurrence. - This species is undoubtedly the most common, found in the northern part of the Argentine Precordillera, but it occurs mainly as isolated furcal rami. Levels of the Acoite Formation which provided us with phyllocarids are assigned to the Tetragraptus akzharensis Zone (locality La Luna) of the Floian, lower Arenig (Be1-Be2, Bendigonian of Australasia), up to the Didymograptus bifidus Zone, of middle Arenig age (Ch1, Chewtonian of Australasia). The species occurs in the Los Colorados section (No. 23266 to 23288), as in Agua Blanca-La Luna section (No. 23240-23243). In the Mina Natasia section, the species is common in the graptolitic shales from the first outcrop along the road, up to the mine entrance, about 1,500 m to the South (No. 23289 to 23318). 

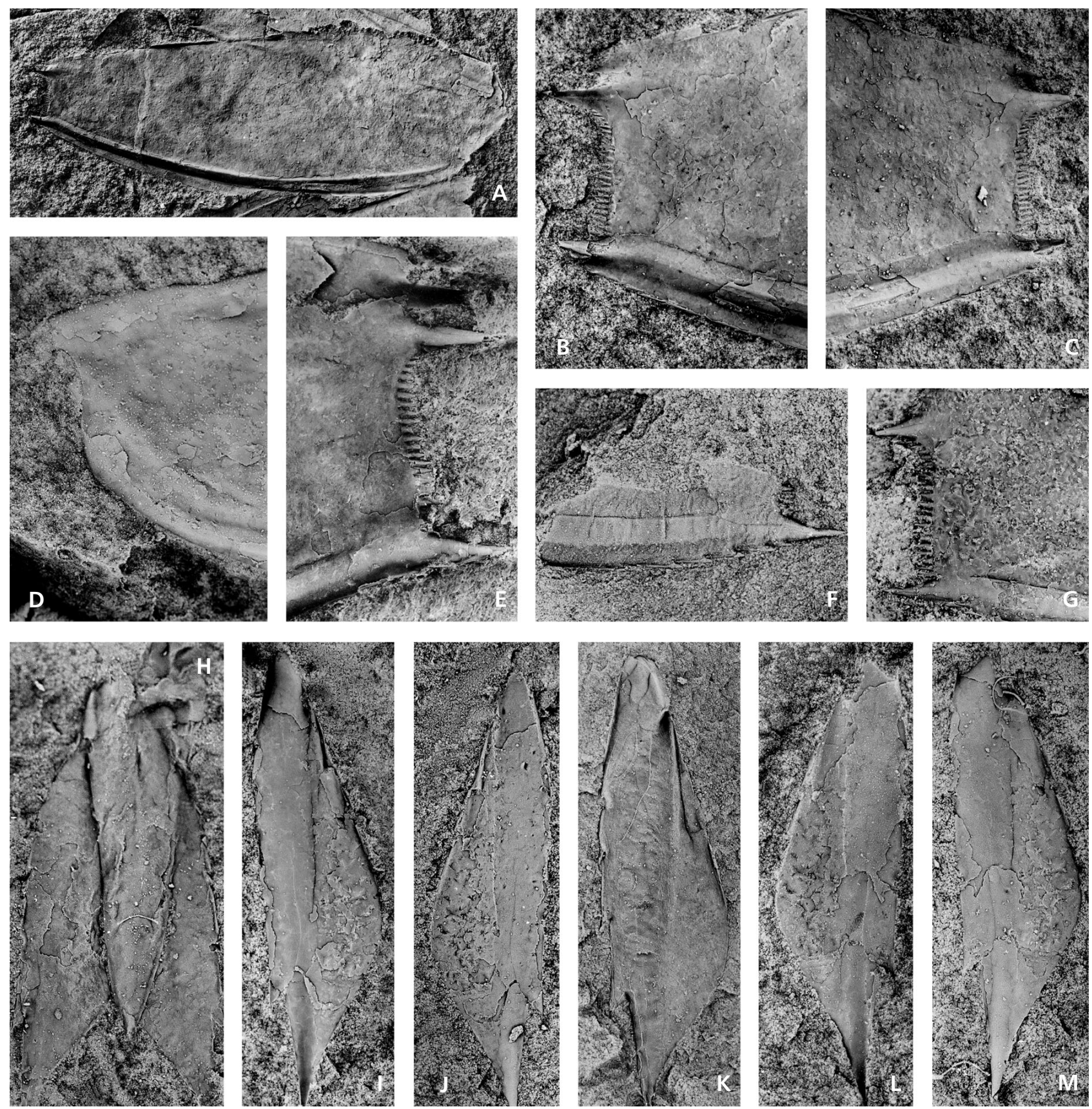

Figure 8. Janviericaris formosa sp. nov. Chapiuno section, type locality, NW of Tarija, Southern Bolivia. $\bullet$ A-C - right valve of the carapace, natural mould (A), holotype MNHNC 13330, $\times 3$, and enlarged views of the posterior part of the carapace showing the sinuous spinose margin on the natural mould (B) and on the latex cast (C) $\times 10$. $・$ D - anterior part of a left valve, MNHNC 13331, showing the subvertical sinuous anterior margin and the base of the anterior horn, $\times 10 . \bullet \mathrm{E}$ - posterior part of a left valve, MNHNC 13332, showing the sinuous spinose margin on the natural mould, $\times 10$. $\bullet \mathrm{F}-$ incomplete posterior part of carapace MNHNC 13333, latex cast, showing the well preserved posterior ventral spines, the posteroventral spine, and a part of the sinuous spinose margin, $\times 10 . \bullet \mathrm{G}$ - posterior part of carapace MNHNC 13334, showing the sinuous spinose margin on the natural mould, $\times 10$. $\bullet \mathrm{H}-$ latex cast of a tail piece MNHNC 13335 showing the telson and the two furcal rami in connection, $\times 10$. $\bullet$ I, J - left furcal ramus MNHNC 13336, natural mould and latex cast, $\times 10 . \bullet \mathrm{K}$ - left furcal ramus MNHNC 13337, natural mould, $\times 10 . \bullet \mathrm{L}, \mathrm{M}-$ right furcal ramus MNHNC 13338, natural mould and latex cast, $\times$ 10. Compare with the camera lucida drawings of Fig. 7 .

The section was sampled in 2000, then in 2001; except for the first outcrop which yields no graptolites, the section is tentatively assigned to the Baltograptus deflexus Zone, i.e. Floian, upper lower Arenig (equivalent to the Be3-Be4,
Bendigomian of Australasia). The species is also known from the Quebrada Saladillo locality (Sierra de Famatina) in beds of the Suri Fm assigned to the Baltograptus deflexus Zone, late Floian. It also occurs in three levels of the 

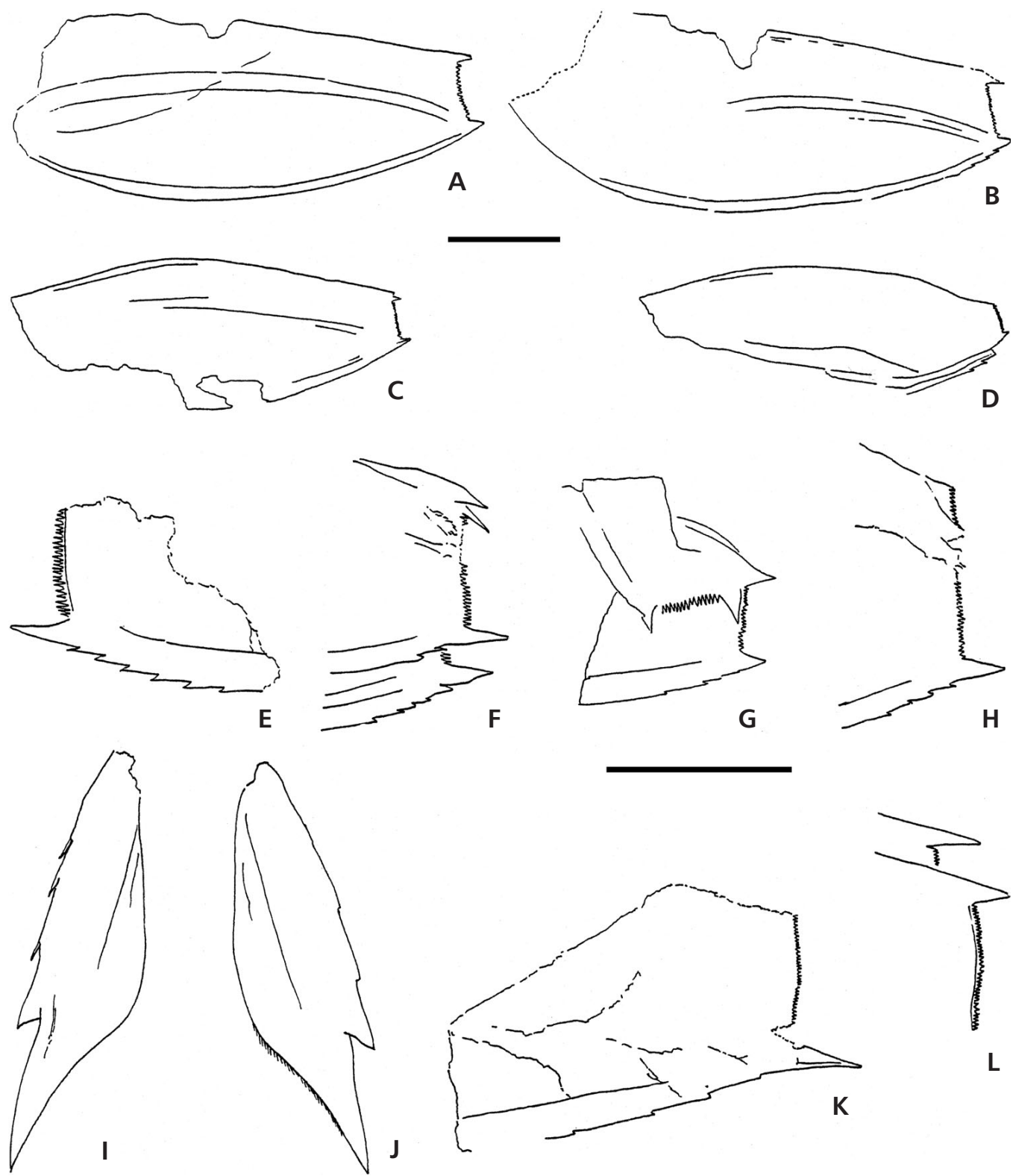

Figure 9. Janviericaris jujuyensis sp. nov. • A, B - left valves from Los Colorados, No. 23271 and 23272 respectively. $\bullet$ C-G - left valves and posterior parts of fragmentary valves from Mina Natasia (localities 3 and 4), No. 23295, 23301, 23267 and 23302, respectively. $\bullet$ H-L - Agua Blanca section, No. $23316,23242,23243$ and 23240, respectively. Scale bar $=5 \mathrm{~mm}$.

Muñayoc section in the Puna area, in late early to middle Arenig levels. In South Bolivia, B. jujuyensis is common both in silts with concretions and fine-grained sansdstone around Cieneguillas, between the coordinates S $21^{\circ} 22^{\prime} 01^{\prime \prime}$, $\mathrm{W} 65^{\circ} 03^{\prime} 66^{\prime \prime}$, and S $21^{\circ} 21^{\prime} 53^{\prime \prime}, \mathrm{W} 65^{\circ} 03^{\prime} 04^{\prime \prime}$. These outcrops of the Cieneguillas Fm. are late Floian-early Dapingian in age.

Diagnosis. - Species of Janviericaris with weakly sinuous posterior margin of carapace and without pre-posterodorsal spines; very small, short spinules numbering 13 to 20 per $\mathrm{mm}$.
Description. - Carapace: Maximum observed length about $15 \mathrm{~mm}$ for a corresponding (estimated) height of $5 \mathrm{~mm}$. Only specimen No. 23308 (Fig. 9C) has its anterior margin preserved; it is angular, pointed, but shows no development of a differentiated horn. Dorsal line gently and evenly arched. Anteroventral margin markedly convex, with a very narrow but well developed marginal rim. Narrow ventral border (approx. $0.6 \mathrm{~mm}$ to $0.7 \mathrm{~mm}$ wide), subtriangular in cross section, dorsally limited by a well impressed ridge running parallel to the whole ventral margin which is evenly, and regularly arched. Posteroventral part of the ventral margin bearing 4 to 6 small, short and posteriorly 


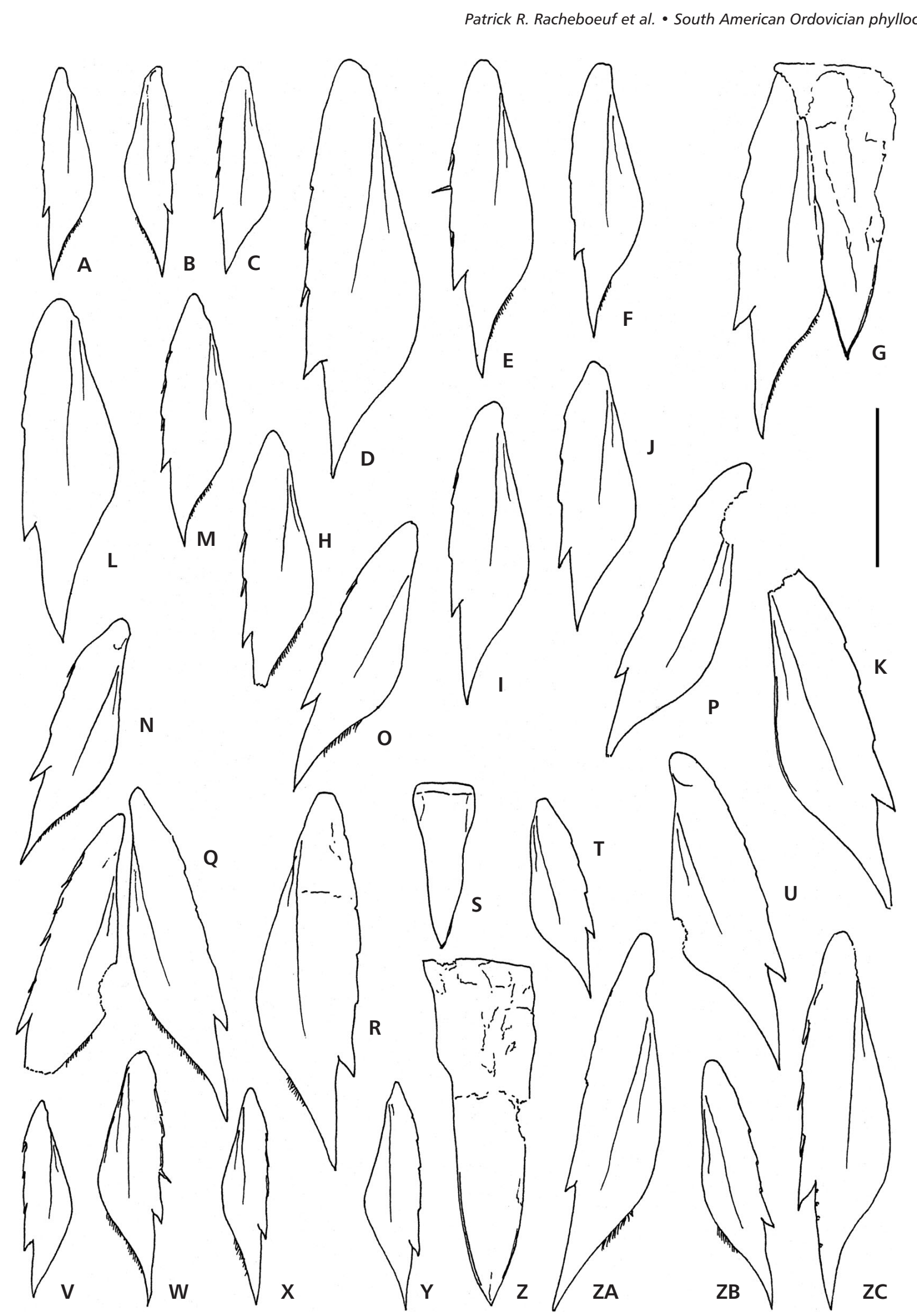

Figure 10. Janviericaris jujuyensis sp. nov. furcal rami, telsons and tailpieces from Los Colorados (A-K), La Luna (L-O), and Mina Natasia (localities 3-4) (P-ZC) sections. • A-F - No. 23274-23279, 23285, and 23286-23288, respectively. • L-O - No. 23280, 23281, 23283, and 23284, respectively. - Q-ZC - No. 23311, 23312, 23300, 23298, 23305, 23316-23318, 23314, 23313, 23315, 23299 and 23297. Scale bar $=5 \mathrm{~mm}$. 
directed, pre-posteroventral spine-like expansions. Ventral margin of the posteroventral spine is a continuation of the ventral margin of the carapace. Posterodorsal and posteroventral spines markedly developed, $2.0 \mathrm{~mm}$ to $3.0 \mathrm{~mm}$ long, the posteroventral one being often slightly longer and thicker than the posterodorsal one. Pre-posterodorsal spines not observed or missing (?). Posterior margin of the carapace sinuous, very weakly convex ventrally, becoming weakly concave dorsally, bearing 18 to 26 posteriorly directed spinules. Spinules decreasing in size slightly towards the dorsal spine. Length of spinules between $0.8 \mathrm{~mm}$ and $1.0 \mathrm{~mm}$.

Ornamentation of the carapace: Except for the longitudinal dorsal and ventral furrows and the top of ridges, as well as the dorsal and ventral margins, which are smooth, the carapace surface is extremely finely granulose and devoid of any other kind of ornamentation.

Abdomen and abdominal somites unknown.

Tail piece: Telson subtriangular, moderately elongate, with lateral margins weakly concave in their anterior part, just after the telson head. Their lateral margins become weakly convex towards the posterior end. Only three available telsons, but one (Fig. 10.G), was found isolated. The dorsal side shows no evidence of any longitudinal ridge or furrow, nor any ornamentation. The length : width (L : W) ratio varies from 2.70 to 3.16 for 3 telsons $5.4 \mathrm{~mm}$ to $11.4 \mathrm{~mm}$ long. Furcal rami elongated. Observed length between $6.4 \mathrm{~mm}$ and $14.4 \mathrm{~mm}$ for 36 specimens; corresponding width between $1.6 \mathrm{~mm}$ and $3.8 \mathrm{~mm}$. L : W ratio varying between 3.52 and 4.56. Maximum width located around the posterior third of the length. Outer margin weakly convex with a unique spine-like expansion, and three to four narrow, acute articulated spines. Inner margin almost straight proximally, becoming convex posteriorly, then variably and moderately concave until joining the terminal spine. Inner convex margin fringed by numerous, short setae. Well differentiated, straight to weakly sinuous submedian longitudinal furrow.

Comparison.-J. jujuyensis sp. nov. is assigned to Janviericaris gen. nov. on the basis of the carapace outline, with a short anterior horn, a markedly straigthened anterior margin, and a weakly sinuous posterior margin, with long, stout posteroventral and posterodorsal spines. The posterior end of the dorsal margin lacks the row of preposterodorsal, well developed spine-like expansions, however furcal rami are similar to those of the type-species, with a unique, posterior, spine-like expansion, and three small, articulated spines. J. jujuyensis sp. nov. differs from J. formosa sp. nov. by its much shorter anterior horn, and by a less markedly sinuous posterior margin with much more numerous, smaller and shorter spinules, numbering 13 to 20 per $\mathrm{mm}$ instead of 6 to 9 per $\mathrm{mm}$ in $J$. formosa sp. nov.

\section{Genus Ivocaris gen. nov.}

Type species. - Caryocaris delicata Racheboeuf, Vannier \& Ortega, 2000.

Etymology. - To honour the late Dr. Ivo Chlupáč for his extensive work on Paleozoic Bohemian arthropods.

Diagnosis. - Caryocaridids with an oblique, spinose posterior margin to the carapace; posterodorsal and posteroventral spines present, or posteroventral spine reduced, or absent; furcal rami without any spine-like triangular expansion, but with a variable number of very small articulated spines along the outer margin.

Discussion. - Ivocaris gen. nov. differs from Caryocaris Salter, by its oblique, sinuous and spinose posterior margin, with reduced or absent posteroventral spine; outer margin of furcal rami with a variable number of small, articulated spines inserted on notches without any flattened spine-like expansion.

Species assigned. - Caryocaris delicata Racheboeuf, Vannier \& Ortega, 2000 (type species); Ivocaris saltitensis sp. nov.

Geographic distribution. - Argentine Precordillera; ?Czech Republic.

Stratigraphic range. - Darriwilian (Uppermost Arenig-Llanvirn).

Comparison. - Ivocaris gen. nov. differs from both $\mathrm{Ca}$ ryocaris and Janviericaris gen. nov. by the oblique posterior margin of the valves, with or without posteroventral spine, as well as by the lack of any flattened spine-like expansion on the outer margin of the furcal rami.

The species Caryocaris (Rhinopterocaris) subula Chlupáč, 1970 from the Dobrotivá Formation of the Czech Republic, is very similar in every aspect of its morphology to the species assigned here to the new genus Ivocaris and especially I. saltitensis sp. nov. Detailed and careful complementary investigations of the furcal rami of the original specimens of $C$. subula described and illustrated by I. Chlupáč (1970) have been made by Petr Budil (Czech Geological Survey). As a result, the outer margin of the furcal rami of $C$. subula bears small, acute, straight, relatively long and narrow cylindrical spines which always exhibit the same attitude, i.e. almost parallel to the outer ramus margin, instead of articulated spines as in $I$. delicata, and $I$. saltitensis sp. nov. Hence Chlupáč's species subula cannot be assigned to Ivocaris gen. nov. 

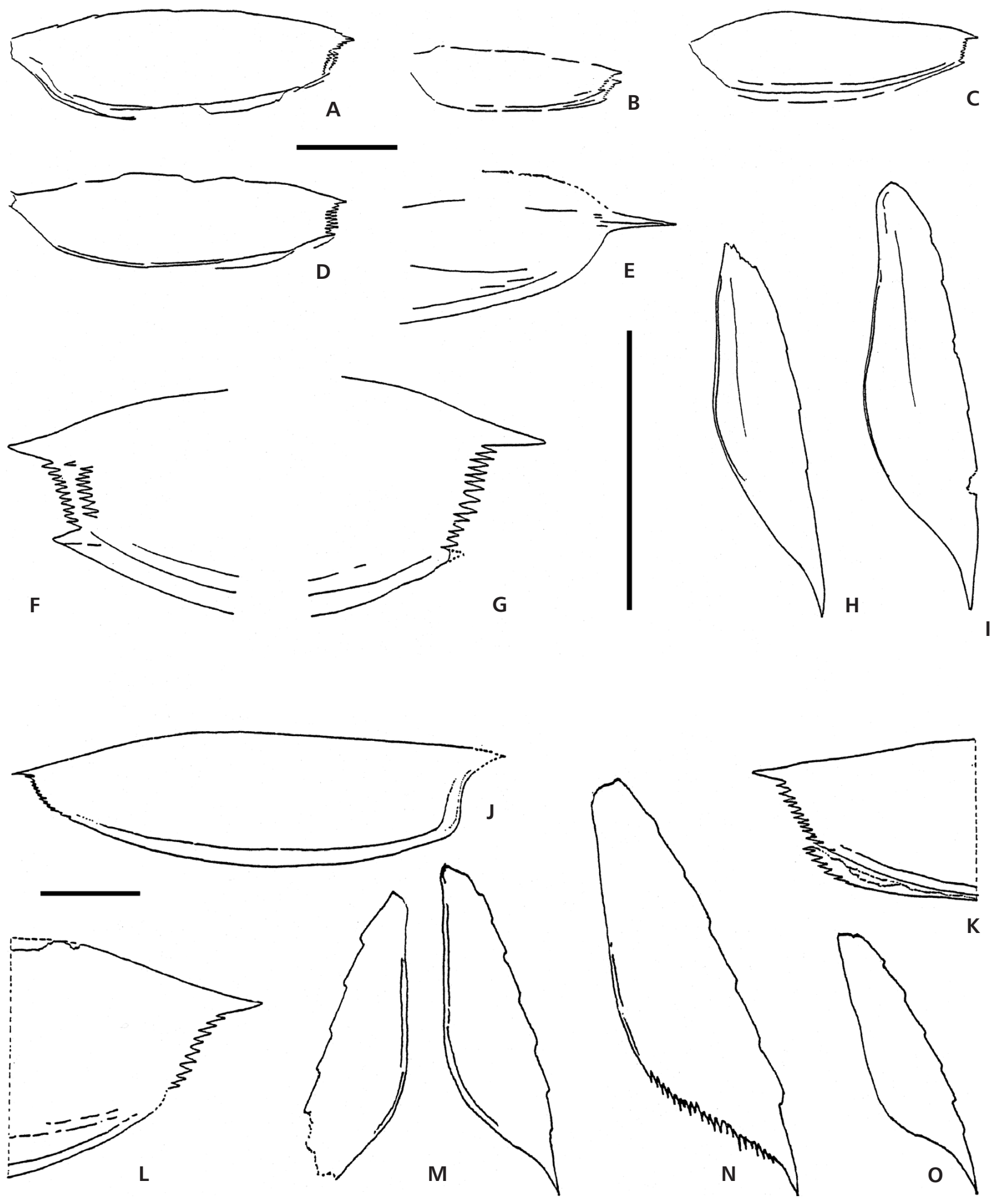

Figure 11. A-I - Ivocaris saltitensis sp. nov. from the lower part of the Los Saltitos section (type locality). $\bullet$ A-D - carapace outline of specimens 23334-23336 and 23339, respectively. • E - anterior horn of specimen CEGH-UNC 16244. • F, G - posterior margin of specimens 23329 and 23330 showing the oblique posterior margin and the posterodorsal and posteroventral spines, the latter being broken on specimen 23329 (Fig. 7). $\bullet \mathrm{H}-$ isolated furcal ramus, 23332. I - isolated fursal ramus, 23331. Scale bar $5 \mathrm{~mm}$. • J-O - Ivocaris delicata Racheboeuf, Vannier \& Ortega, 2000. J - holotype, right valve of the carapace, CORD PZ 13073. K - posterior margins of both valves of an almost complete carapace, CORD PZ 11546. L - posterior margin of left valve CORD PZ 13073. M - furcal rami of presumably the same tail piece, CORD PZ 14159. N - large isolated furcal ramus with setae preserved along inner margin, CORD PZ 13256. O - isolated furcal ramus, CORD PZ 13211. Scale bar $=5 \mathrm{~mm}$. 
Ivocaris delicata (Racheboeuf, Vannier \& Ortega, 2000) comb. nov.

Figure $11 \mathrm{~J}-\mathrm{O}$

2000 Caryocaris delicatus Racheboeuf, Vannier \& Ortega, p. 323.

2004 Caryocaris delicatus. - Racheboeuf, pp. 258, 260.

Type locality. - Los Azules Creek, Cerro Viejo Range, Huaco, Argentine Precordillera.

Material and occurrence. - Nineteen variably preserved carapaces, 3 tail pieces and 10 furcal rami from the lower member (Undulograptus dentatus Zone) and middle member (Pterograptus elegans and Hustedograptus teretiusculus Zones) of the Los Azules Formation, Darriwilian. Specimens housed in the Museo de Paleontología de Córdoba (No. CORD PZ 12292, 12681, 12846, 12860, 13073, $13211,13253,13256,14150$, and 14159).

Description. - See Racheboeuf et al. 2000, pp. 323-327.

Discussion. - The species was initially described from the lower and middle members of the Los Azules Fm. (Argentine Precordillera), in beds belonging to the Undulograptus dentatus Zone of early Darriwilian age (lower member) and in beds belonging to the Pterograptus elegans and Hustedograptus teretiusculus Zones of middle to upper Darriwilian age (middle member).

Comparison. - The species delicata remains up to now unique among caryocaridids by its lack of a posteroventral spine associated with an oblique posterior margin. It differs from Caryocaris subula Chlupáč, 1970, by a longer-sized carapace (length is about $24 \mathrm{~mm}$, i.e. twice the length of the carapace of $C$. subula), by the lack of the posteroventral spine of the carapace, by curved and less spinose posterior carapace margin and by articulated small spines along the outer margin of furcal rami instead of 'ordinary' spines.

\section{Ivocaris saltitensis sp. nov.}

Figure 11A-I

Etymology. - From the type locality Los Saltitos.

Holotype. - Specimen No. 23336, left valve of the carapace (Fig. 11.C).

Type locality. - Quebrada Los Saltitos, SW Guandacol, La Rioja Province, Northern Argentine Precordillera.

Material and occurrence. - Ten carapaces and three isolated furcal rami from the type locality. Lowermost part of the Gualcamayo Formation (between $0.10 \mathrm{~m}$ and $4.80 \mathrm{~m}$ above the base); No. CEGH-UNC 16221, 16244; No. 23329 to 23339. Upper part of the Undulograptus austrodentatus Zone (U. sinicus Subzone), uppermost Arenig-Llanvirn (equivalent to the Dariwillian Da1).

Diagnosis. - Species of Ivocaris with moderately convex anteroventral margin and present, although reduced, posteroventral spine; oblique posterior margin bearing 10 to 12 spinules; furcal rami markedly elongated with 4 to 5 articulated spines.

Description. - Carapace markedly elongated. Length between $14.5 \mathrm{~mm}$ and $17.5 \mathrm{~mm}$ for the three best preserved specimens; corresponding height varying from $4.3 \mathrm{~mm}$ to $5 \mathrm{~mm}$; length - height ratio $(\mathrm{L}: \mathrm{H})$ between 3.3 and 3.6. Dorsal margin regularly and moderately convex; ventral margin similarly arched. Anterior horn long (about $3.5 \mathrm{~mm}$ ) and narrow. Anteroventral margin regularly arched and moderately convex. Narrow ventral border (approx. $0.5 \mathrm{~mm}$ wide). Both posterodorsal and posteroventral spines present, the latter being shorter, between half and three-quarters the length of the former which is about $1.2 \mathrm{~mm}$ long in specimen 23.329. No pre-posteroventral spine-like expansions. The posterior margin of the carapace is oblique, and its overall outline makes an angle of about $70^{\circ}$ with a theoretical, straight and horizontal dorsal line. Ten to twelve short triangular spinules (about $0.3 \mathrm{~mm}$ long) are inserted along the posterior margin (Fig. 11F, G).

Abdomen and abdominal somites unknown.

Tail piece: telson unknown. Furcal rami markedly elongated; the lengths of two well preserved specimens are $7 \mathrm{~mm}$ and $8 \mathrm{~mm}$ with corresponding widths of $1.6 \mathrm{~mm}$ and $1.8 \mathrm{~mm}$, respectively. Maximum width at mid length. Length : width ratio between 4.26 and 4.3. Outer margin with 4 to 5 notches suggesting 4 to 5 articulated spines. No setae observed. Longitudinal furrow weakly sinuous, close to the longitunal median axis of each furcal ramus.

Discussion. - The new species is assigned to the genus Ivocaris on the basis of the markedly oblique posterior margin of the carapace and on the morphology of the furcal rami which are identical to those described for C. delicata. However, the carapace of $C$. saltitensis sp. nov. differs mainly in its posterior margin which exhibits a posteroventral spine, although shorter than the posterodorsal spine, which is always lacking in $C$. delicata. According to the development of the anterior horn (as deduced from specimen CEGH 16244) and to the presence of a posteroventral spine, C. saltitensis sp. nov. resembles C. (Rhinopterocaris) subula Chlupáč, 1970 from the Šárka and Dobrotivá formations (Darriwilian) of the Barrandian area, but the new species can be distinguished by a relatively shorter anterior horn and a more developed posteroventral spine. The 

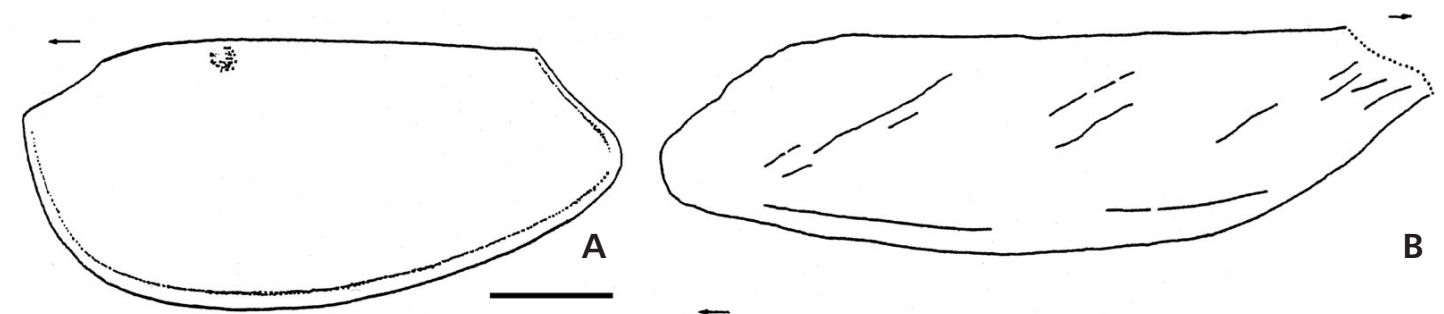

B
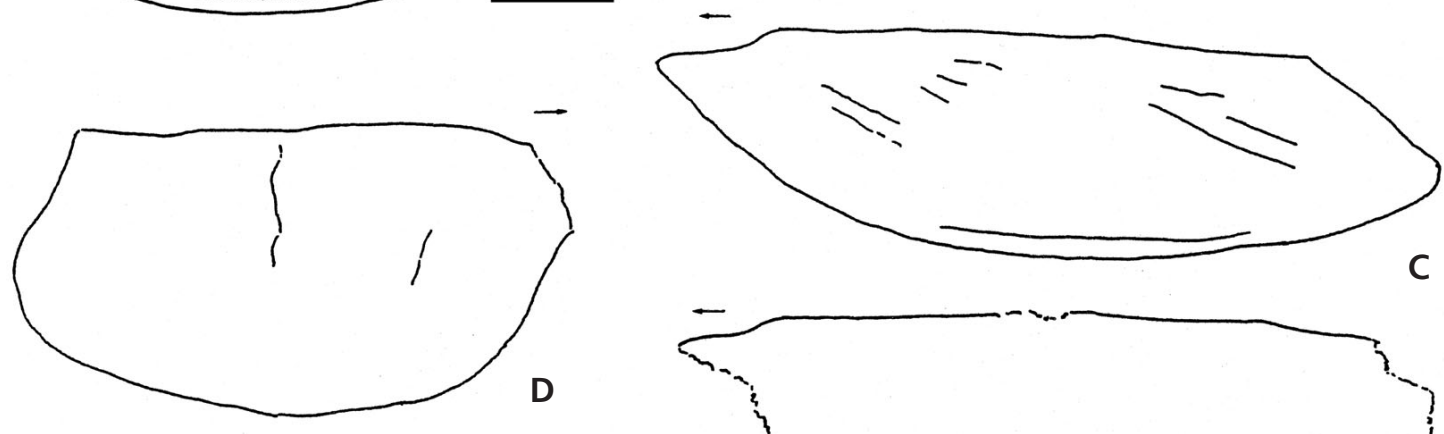

C

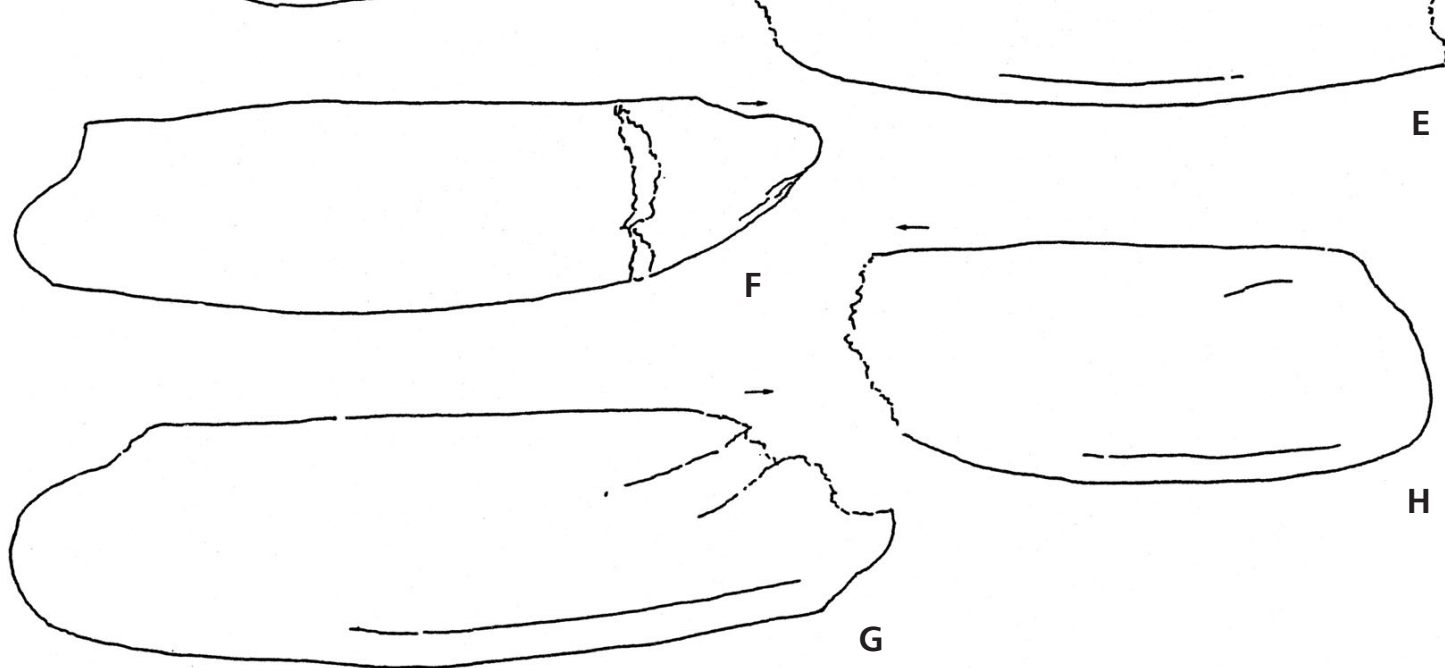

Figure 12. Genus Pumilocaris. Camera lucida drawings of carapaces. A - Pumilocaris granulosa Racheboeuf, Vannier \& Ortega, 2000, late Sandbian (early Caradoc) of the Argentine Precordillera, reconstruction drawn from the holotype CORD PZ 19371. • B-H - Pumilocaris acuta (Bulman, 1931), Caradoc of Huichiyuni, Peru, original specimens of Bulman housed in the Riksmuseum in Stockholm. B, C - both sides of a right valve, specimens Ar 42450 and 42454 (specimen 427 from Bulman 1931, text-fig. 41, upper) respectively. D - right valve, Ar 42451 (specimen 107 of Bulman 1931 , textfig. 41, lower). E - right valve, Ar 42452. F - left valve, Ar 42459. G - right valve, Ar 42467. H - left valve, Ar 42453. Arrows indicate the anterior side. Scale bar $=2 \mathrm{~mm}$.

posterior margin of $I$. saltitensis sp. nov. bears 10 to 12 spinules instead of about 20 in I. delicata, and about 15 in $C$. (R.) subula.

Family Ceratiocarididae Salter, 1860

\section{Genus Pumilocaris Racheboeuf, Vannier \& Ortega, 2000}

Type species. - Pumilocaris granulosus Racheboeuf, Vannier \& Ortega, 2000.

Emended diagnosis. - Ceratiocaridid with subovate carapace, rounded posteroventral margin, and oblique, concave posterodorsal margin; no spines nor spinules; anterior margin markedly convex, with an anterodorsal concave margin suggestive of a (?)frontal incision or of a rostral plate; variably developed ventral border; valve surface finely granulose.

Species assigned. - Pumilocaris granulosus Racheboeuf, Vannier \& Ortega, 2000 (type species); Caryocaris acuta Bulman, 1931.

Geographic distribution. - South America (Argentina, Peru).

Stratigraphic range. - Caradocian. 
Pumilocaris granulosa Racheboeuf, Vannier \& Ortega, 2000

Figure $12 \mathrm{~A}$

2000 Pumilocaris granulosus Racheboeuf, Vannier \& Ortega, p. 328.

2004 Pumilocaris granulosus. - Racheboeuf; p. 260, fig. 25.1.

Etymology, diagnosis and description. - See Racheboeuf et al. 2000.

Remarks. - Pumilocaris granulosa is restricted to the early Caradoc beds of the Las Plantas Formation (Argentine Precordillera, western side of the Cerro Potrerillo section NE of Jachal, San Juan Province), where it is associated with Climacograptus bicornis, Nemagraptus gracilis and Orthograptus ssp. assigned to the C. bicornis Zone (see Racheboeuf et al. 2000), early Caradocian.

Pumilocaris acuta (Bulman, 1931) comb. nov. Figure 12B-G

1931 Caryocaris acuta Bulman, p. 84, text-fig. 41, pl. 11, fig. 7.

2004 ?Pumilocaris acuta. - Racheboeuf, p. 260, fig. 25.1.

Discussion. - The species acuta was originally described from the Huichiyuni section of Peru, North of Lake Titicaca. Specimens Ar 42461 and 42462 are associated with graptolites which can be assigned to Dicranograptus cf. $n i$ cholsoni and specimen Ar 42466 is associated with Dicranograptus $\mathrm{sp}$. These graptolites suggest a late Darriwilian to Sandbian age.

Although poorly preserved and tectonically distorted Bulman's specimens from the Peruvian locality Huichiyuni are assigned to the genus Pumilocaris, mainly with regard to the posterior region of the carapace which is devoid of any spinose ornamentation and which exhibits the characteristic convex outline becoming concave when reaching the dorsal margin. Despite distorsion, Pumilocaris acuta differs clearly from the type species $P$. granulosa by its larger size, its more rounded posterior margin and wider ventral border. The anterodorsal node and the granulose ornamentation described in the type species could not be observed in $P$. acuta.

Dimension of the carapaces (in $\mathrm{mm}$ ).

$\begin{array}{lrr}\text { Specimen Ar No. } & \text { Length } & \text { Height } \\ 42450 & 12.0 & 3.5 \\ 42451 & 8.5 & 4.5 \\ 42452 & 12.5 & 3.2 \\ 42456 & 8.5 & 2.6\end{array}$

Genus Rolfecaris gen. nov.

Type species. - Rolfecaris lethiersi sp. nov.

Etymology. - To honour Dr. W.D. Ian Rolfe for his extensive work on phyllocarids.

Diagnosis. - Carapace elongate, subovate in outline, with straight hinge line, covering thoracic and abdominal somites; no median dorsal plate, nor rostral plate; anterior and posterior margins rounded, markedly arched dorsally to join hinge line; well differentiated and flat ventral border; carapace ornamented with thin, sinuous and irregular, non anastomosing longitudinal striae; tail piece with an elongate, rodlike telson, subtriangular in cross section, longitudinally grooved and bearing numerous articulated spinules; furca rodlike, devoid of spinules, subcylindrical in cross section and about the same length as the telson.

Discussion. - The new genus is here only tentatively and provisionally assigned to the Family Ceratiocarididae as diagnosed in the Treatise (Rolfe 1969). Such a family assignment relies upon the overall outline and characters of the carapace, the absence of a median dorsal plate and on the morphology of the tail piece with a long, narrow, rodlike, spinule bearing telson and long, rodlike furca. However, Rolfecaris strongly differs from Ceratiocaris in the oval outline of the carapace which is apparently devoid of anterior horn or rostral plate (?), and in the fact that the carapace covers thoracic and all abdominal somites, as evidenced by nearly complete specimens of the type species. The outline of the carapace resembles Heroldina Broili, 1931 from the Lower Devonian of Germany, but Heroldina bears a large rostral plate and exhibits a well developed abdomen and its tail piece is devoid of rodlike furca (Rolfe 1969, p. R317). The ornamentation of the carapace of Rolfecaris with thin, sinuous longitudinal striae, is very similar to that of the ceratiocaridids and it resembles that of the Silurian genus Gonatocaris (Rolfe 1969, p. R316). No hinge nodes nor tubercles could be observed on the available material.

Species. - Rolfecaris lethiersi sp. nov. (type species); Rolfecaris parchaensis sp. nov.

Geographic distribution. - Northwestern Argentina.

Stratigraphic range. - Parcha and Acoite formations, late Tremadocian to early Floian. 
Rolfecaris lethiersi sp. nov. Figures 13, 14

2004 gen. et sp. nov. (pars), Racheboeuf, p. 260, fig. 25.1.

Etymology. - To honour Dr. F. Lethiers for his extensive work on Devonian ostracodes.

Holotype. - Incomplete left valve of the carapace with proximal part of the tail piece still attached, No. 23259, Fig. $14 \mathrm{~A}$.

Type locality. - Agua Blanca section, about $30 \mathrm{~km}$ WNW of Purmamarca (Provincia de Jujuy); coordinates S $23^{\circ}$ $40^{\prime} 48^{\prime \prime}, \mathrm{W} 65^{\circ} 42^{\prime} 43^{\prime \prime}$.

Material and occurrence. - A total of 21 specimens (11 carapaces, of which six still with connected telson; four more or less complete tail pieces and six isolated telsons) collected by Dra Blanca Toro (Mendoza) from the Acoite Formation. An isolated telson (No. 23326) was collected in the section along the trackway between road 52 and Mina Natasia, sample 4, in front of the entrance of the mine; coordi-

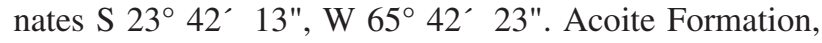
Tetragraptus phyllograptoides to T. akzharensis Zones, early Floian. All specimens are housed in the collection of the La Pampa University (Santa Rosa) under numbers 23244 to 23264 , and 23326.

Diagnosis. - As for the genus.

Description. - Small, elongate, subovate carapace; maximum length observed ca. $19.0 \mathrm{~mm}$ for a corresponding height of $8.7 \mathrm{~mm}$; length/height ratio varying between 2.0 and 2.2 for seven more or less complete carapaces. Hingeline present as deduced both from the "butterfly" position of some specimens (23235) and isolated valves of others. Dorsal margin of the valves straight for most of its length, with a markedly arched anterodorsal extremity and a less convex posterodorsal one. Anterior and posterior margins of the carapace probably rounded and regularly convex. Ventral margin moderately and regularly convex, with a flat, relatively wide $(0.6 \mathrm{~mm}$ to $1.1 \mathrm{~mm})$ ventral border. Valve surface covered with thin, sinuous, non anastomosing, spaced and irregular longitudinal striae. Dorsally, striae relatively short, almost straight and parallel to the dorsal margin; ventrally, striae becoming longer, more spaced ventrally and curved, following the curvature of the ventral furrow.

Ventral margin with very thin, dense, sinuous and oblique striae.

Telson head relatively stout and rounded, subtriangular, concavoconvex in cross section. In dorsal view the telson is subtriangular in outline, with weakly concave lateral margins. The width of the telson diminishes progres-

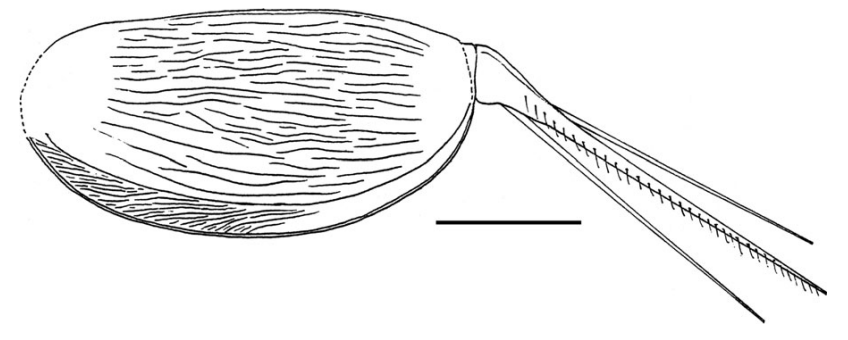

Figure 13. Rolfecaris lethiersi gen. et sp. nov. Tentative reconstruction of the complete exoskeleton, mostly after specimens illustrated in Fig. 14. Note that stylets are straight; it is not clear whether the curvature of the stylets observed on specimens No. 23251 and 23252 results from distorsion or not. Scale bar $=5 \mathrm{~mm}$.

sively from its proximal part to the anterior third of its total length. Each lateral side of the telson bears a row of very small pits corresponding to the attachment of very small spinules. Spinules appear to be distributed from the posterior extremity of the telson head almost to the extremity of the telson. The density of spinules varies from 6 to 8 per $2 \mathrm{~mm}$. Furca long and narrow, rodlike, subcylindrical in cross section, without spinules or setae. In specimen 23252, the length of the left furca equals about that of the telson (about $10 \mathrm{~mm}$ ), with a diameter of $0.2 \mathrm{~mm}$.

Dimensions (in mm).

$\begin{array}{lr}\text { Specimen No. } & \\ 23244 & 7.8 \\ 23245 & 8.7 \\ 23256 & 6.7 \\ 23258 & 2.6 \\ 23259 \text { (holotype) } & 6.9 \\ 23263 & \\ 23264 & 6.5\end{array}$

\begin{tabular}{rrr}
\multicolumn{3}{c}{ Carapace } \\
L & $\mathrm{H}^{\prime}$ & $\mathrm{L} / \mathrm{H}$ \\
$? 16.5$ & 1.1 & 2.11 \\
$? 19$ & 0.7 & 2.18 \\
$?$ & 0.6 & - \\
$? 5.7$ & 0.4 & 2.19 \\
14.0 & 1.0 & 2.02 \\
$?$ & 0.9 & - \\
$?$ & 0.6 & -
\end{tabular}

$\begin{array}{lrrr} & & \text { Telson } & \text { Furca } \\ \text { Specimen No. } & \mathrm{L} & \mathrm{W} & \mathrm{d} \\ 23248 & 7.5(+) & - & - \\ 23249 & 7.5(+) & - & - \\ 23250 & 9.0 & - & - \\ 2325 & 10.0(+) & 1.7 & 0.2 \\ 23253 & ? 5.5 & 0.6 & 0.1 \\ 23254 & 13.0 & - & -\end{array}$

\section{Rolfecaris parchaensis sp. nov.}

Figure 16

2000 ?Pumilocaris sp. - Racheboeuf et al., p. 331, fig. 11.

2000 Undetermined phyllocarid. - Racheboeuf et al., p. 331 , fig. 12 .

2004 gen et sp. nov. (pars), Racheboeuf, p. 260, fig. 25.1. 
Etymology. - From the stratum typicum, the Parcha Formation.

Holotype. - Left valve of the carapace, No. 23231, Fig. 16A.

Type locality. - Incamayo creek, about $3 \mathrm{~km} \mathrm{~N}$ of Incahuasi, Argentine Eastern cordillera (Salta Province).

Material and locality. - A total of 11 specimens (eight isolated valves and three incomplete tail pieces) from the type locality, collected by Gladys Ortega (No. CORD PZ 18924, 18962, 19075 of the Córdoba University collection) and by Beatriz Waisfeld (No. 23231 to 23238 of the La Pampa University collection) from Huaico Hondo; both localities belong to the Parcha Formation and comprise the Aranaeograptus murrayi and Hunnegraptus copiosus Zones (late Tremadoc).

Description. - Small, elongate, subovate carapace; maximum length observed is ca $9.0 \mathrm{~mm}$ for a corresponding height of $3.8 \mathrm{~mm}$; length/height ratio varying between 2.0 and 2.36 for nine more or less complete carapaces. Dorsal hinge present as deduced both from the "butterfly" position of some specimens (23235) and isolated parts of the carapace. Dorsal line weakly sinuous, with an accentuated curved anterodorsal part and an almost rectilinear posterodorsal part. Anterior and posterior margins of the carapace probably rounded and regularly convex. Ventral margin moderately and regularly convex, with a narrow $(0.12 \mathrm{~mm}$ to $0.18 \mathrm{~mm}$ high $)$ ventral border.

Discussion. - This small species can only be assigned to the new genus Rolfecaris. Carapace outline, as well as length-height ratio are very close to $R$. lethiersi, but it differs in its much narrower, almost linear ventral border; this is particularly evident when comparing ?R. parchaensis with juvenile specimens of $R$. lethiersi (see Figs 14 and 16). ?R. parchaensis also differs by the apparent lack of lateral spinules on the telson.

Dimensions (in mm). -

Specimen No. $\quad \mathrm{H}$ 23231 (holotype) 3.43

23232

\section{Carapace}

L

7.5

H'

0.15

$\mathrm{L} / \mathrm{H}$ ratio 2.18

7.06

7.18

0.3

2.22

0.18

2.34

6.25

$-$

2.00

0.12

0.12

6.87

2.19

2.07

2.09

2.36

\section{Undetermined phyllocarids}

Despite the efforts we made during field work, several levels, and/or localities, of the South American Ordovician succession provided us with only scarce and poorly preserved phyllocarid remains. Carapaces were often spirally coiled, distorted and preserved in coarse-grained deposits. These forms which cannot be figured here can only be questionably assigned to the Family Caryocarididae and they are mentioned here in Fig. 2 as 'Caryocaris' sp. A, sp. B, and sp. C. All these specimens are from upper Ordovician levels.

\section{'Caryocaris' sp. A}

Locality and age. - Quebrada Los Azules, upper member of the Los Azules Formation, at $2.20 \mathrm{~m}$ and $8.40 \mathrm{~m}$ below the top of the formation, late Sandbian age.

Material. - Six isolated valves and fragments of carapaces (No. 23348-23353).

\section{'Caryocaris' sp. B}

2000 ?Caryocaris sp. 2; Racheboeuf, Vannier \& Ortega, p. 328.

Locality and age. - Western side section of the Cerro Potrerillo, NE of Jachal, San Juan Province, Northern Argentina, Miembro Las Plantas, Las Vacas Formation, Climacograptus bicornis Zone, late Sandbian age.

Material. - Four very poorly preserved carapaces (No. 23354-23357).

\section{'Caryocaris' sp. C}

Locality and age. - Quebrada Zanja Honda, Cerro Negro, Trapiche Formation, early Katian age.

Material. - A unique poorly preserved carapace (No. 23328).

\section{Ordovician phyllocarid taxonomic diversity}

The diversity and vertical range of South American Ordovician phyllocarid taxa were previously dealt with in three recent publications (Racheboeuf et al. 2000, Vannier et al. 2003, Racheboeuf 2004), and all known data drawn from the literature are summarized in Table 1 here. Table 2 gives 

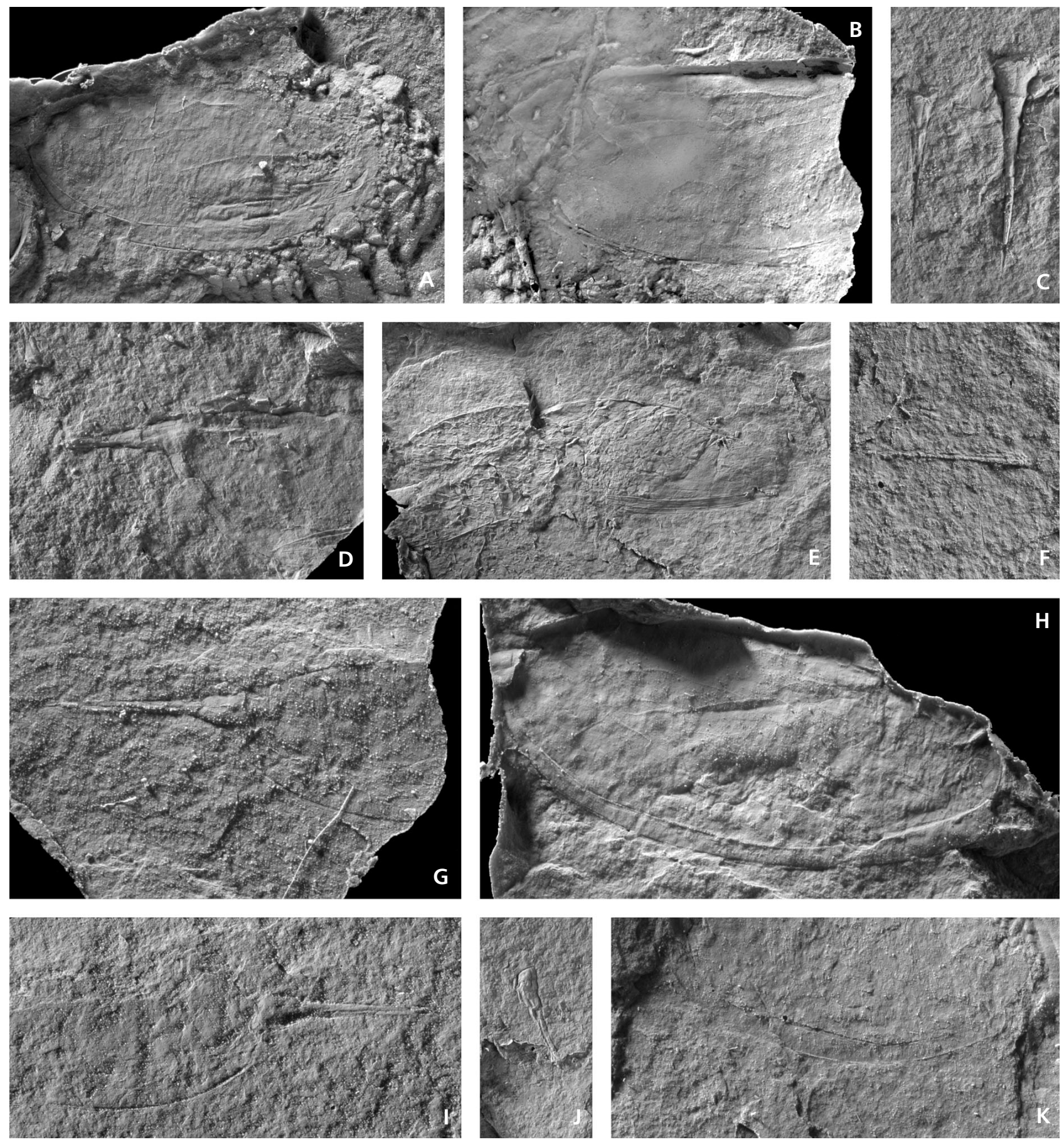

Figure 14. Rolfecaris lethiersi gen. et sp. nov. Agua Blanca section (type locality) sample 7 of Blanca Toro. All figures are latex casts. All specimens $\times 5$. $\bullet$ A - incomplete left valve of the carapace with proximal part of the tail piece still attached, holotype No. 23259. $\bullet$ B - incomplete right valve, No. 23346. $\bullet$ - two isolated telson, No. 23258. $\bullet$ D - posterior part of an incomplete right valve with telson still articulated, No. 23257. $\bullet$ E - right valve, No. 23240. $\bullet \mathrm{F}$ - isolated telson, No. 23254. $\bullet \mathrm{G}-$ posterior part of an incomplete right valve with telson still articulated, No. 23262 . $\bullet \mathrm{H}-$ large right ventral valve, No. 23255 . $\bullet \mathrm{I}$ - posterior part of a left valve with articulated telson, No. 23261 . $\bullet \mathrm{J}$ - small isolated telson, No. 23260 . $\bullet \mathrm{K}-$ ventral margin of an incomplete right valve, No. 23264.

a list of all Ordovician phyllocarid taxa described throughout the world, including those described in this paper.

Following the Treatise (Rolfe 1969), Ordovician representatives of the subclass Phyllocarida belong to two or- ders, namely Hymenostraca Rolfe, 1969 (?Early Cambrian, Middle Cambrian-Middle Ordovician) and Archaeostraca Claus, 1888 (Early Ordovician-Late Triassic). Representatives of the Order Hymenostraca are as a 
whole characterized by a carapace devoid of a hinge line and by three pairs of caudal spines, both characters which clearly distinguish hymenostracans from archaeostracans. Hymenostracans still remain poorly known and their phyletic relationships are still questionable (Rolfe 1969, p. 314). Nevertheless, none of the phyllocarid specimens found in South America could actually be assigned to the Order Hymenostraca and that order will not be discussed below, although some species initially described under the genus name Hymenocaris could now be more accurately assigned to Caryocaris (see below).

According to the Treatise (Rolfe 1969) five archaeostracan genera (Caryocaris Salter, 1863; Ceratiocaris McCoy, 1849; Nothozoe Barrande, 1872; Saccocaris Salter, 1863, and Trigonocarys Barrois, 1891) have been described from - or are known to occur in - Ordovician strata throughout the world. The last three genera are assigned to uncertain order and family (Rolfe 1969, p. 323). The genus Rhinopterocaris Chapman, 1903, is considered to be a junior synonym of Caryocaris, whereas Lamprocaris Želízko, 1919 is considered to be a nomen nullum (Rolfe 1969, p. R316, Chlupáč 1970), whilst Dawsonia Nicholson, 1873 is no more considered to be a phyllocarid genus (Page, in press).

Chlupáč (1970) described the Bohemian genus Mytocaris under 'subordo et familia incerta' and considered Rhinopterocaris Chapman, 1903, to be a subgenus of Caryocaris. Bassett \& Berg-Madsen (1993) assigned the Ordovician genus Protocimex Moberg, 1892 from Sweden (initially described as an insect wing) to the Phyllocarida. They stated that Protocimex has to be considered as a nomen dubium, though they regarded Protocimex to be a probable junior synonym of Caryocaris (Bassett \& BergMadsen 1993, p. 144). More recently Racheboeuf et al. (2000) rejected Trigonocarys from the phyllocarids and proposed the family Caryocarididae for the genus Caryocaris only; they considered Rhinopterocaris to be a junior synonym of Caryocaris and they described the genus Pumilocaris from the Late Ordovician of Argentina, which they assigned to the family Ceratiocarididae.

As a consequence, most Ordovician representatives of Archaeostraca presently belong to either the Family Caryocarididae, or the Family Ceratiocarididae, with exception of the genera Nothozoe, Saccocaris and Mytocaris which still remain of uncertain affinities among phyllocarids as explained above.

Among the Family Caryocarididae, the new concept of the genus Caryocaris developed in the present paper leads to the description of two new caryocaridid genera on the basis of selected morphological characters (see the taxonomic discussion below), namely Janviericaris gen. nov., and Ivocaris gen. nov. The Family Caryocarididae now includes three genera namely Caryocaris Salter, 1863, Ivocaris gen. nov. and Janviericaris gen. nov.
South American representatives of the Family Ceratiocarididae are Pumilocaris Racheboeuf et al. 2000, and Rolfecaris gen. nov. Despite several references in the literature (for example Branisa 1965), no representative of the genus Ceratiocaris could up to now be identified among specimens in collections or among newly collected material. References to Ceratiocaris most probably correspond to large, poorly preserved caryocaridid specimens. Therefore South American Ordovician occurrences of Ceratiocaris remain speculative or uncertain (Rolfe 1969, p. 315).

Although undoubtedly far from complete, the worldwide generic diversity of Ordovician phyllocarid crustaceans actually includes five genera belonging to two families (Caryocarididae and Ceratiocarididae). Other taxa have been illustrated without description, such as the two probably new archaeostracans (among which a possible ceratiocaridid) from the Middle Ordovician of Oklahoma (North America) (Hannibal \& Feldmann 1997).

According to the literature, 28 species names (among which several probable synonyms) and one subspecies have been described under the genus name Caryocaris between 1863 and 2000 (Table 2). They range from the Tremadocian to the Hirnantian with the recent description of Caryocaris cedarbergensis Whittle et al. (2007) from South Africa. The distribution of taxa cited and/or figured in the literature as Caryocaris sp. was given in Vannier et al. (2003) and it is not taken into account here. Among the species that can be actually considered to belong to Caryocaris (see Table 2), fifteen species have been defined on carapaces only; four other species have been described based on furcal rami only; five other species are known both by their carapace and tail piece, while 2 species have been described from complete exoskeletons. Each of the two new caryocaridid genera proposed here, namely Janviericaris gen. nov. and Ivocaris gen. nov. includes two species, as in the two ceratiocaridid genera, Pumilocaris and Rolfecaris gen. nov.

\section{Conclusion}

This paper provides the first accurate tentative inventory and description of the Ordovician phyllocarid fauna from South America. It includes nine species belonging to five genera from the Tremadocian-Sandbian time interval, while the upper Sandbian and the lower Katian provided us with three other forms still in open nomenclature. Such a diversity has no equivalent in the world at the moment and it does not include the 21 forms of Caryocaris sp. found in the literature and which have not been revised or studied. This South American diversity is undoubtedly directly related to the development of the graptolitic black 

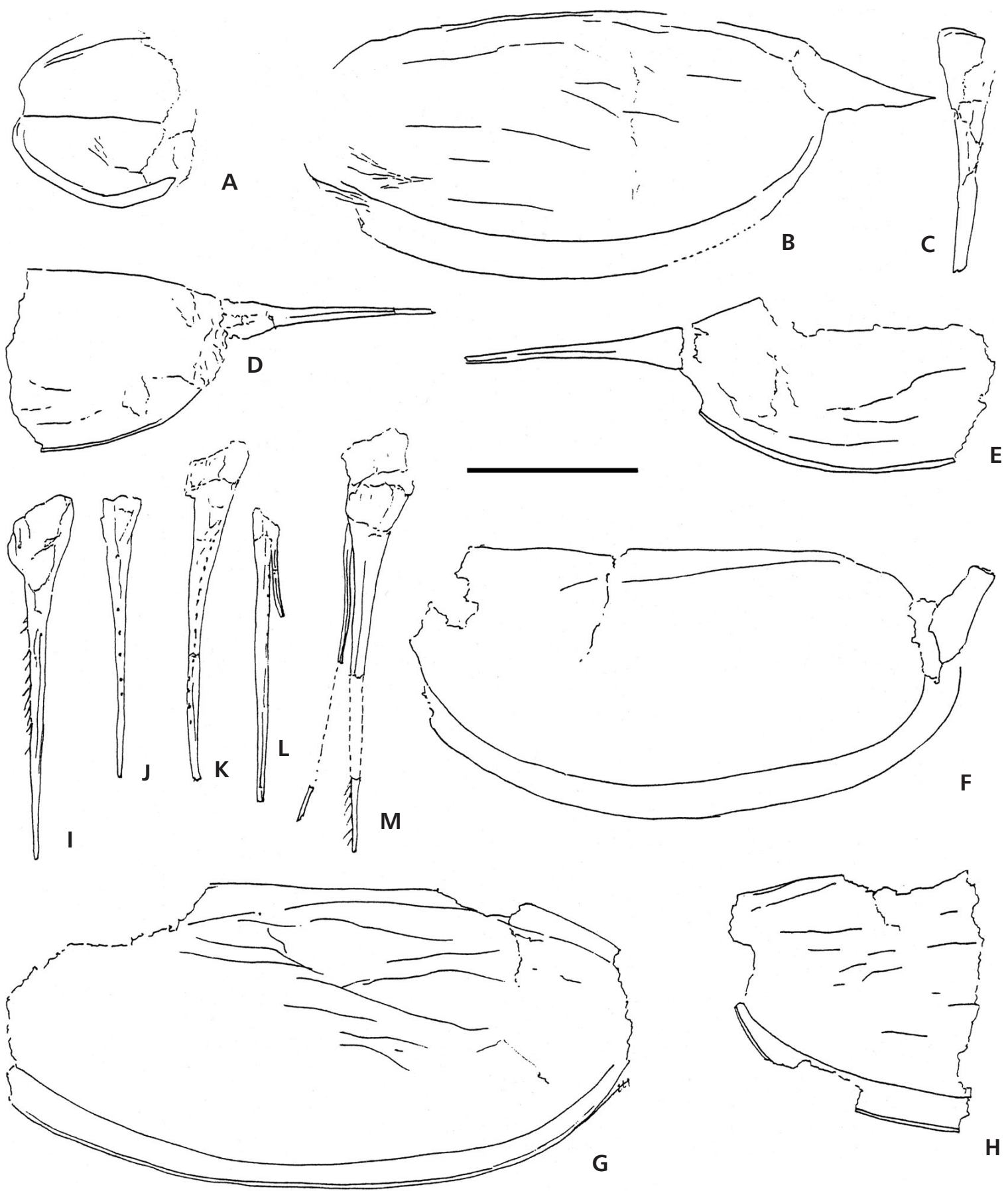

$\mathrm{H}$

Figure 15. Rolfecaris lethiersi gen. et sp. nov. Camera lucida drawings of carapaces and tail pieces. All specimens from the Agua Blanca section (type locality) sample 7 of Blanca Toro, except Fig. 15I from Mina Natasia section. Acoite Formation, Tetragraptus approximatus to T. akzharensis Zones, early Floian (early Arenig). Scale bar $=5 \mathrm{~mm}$. A - juvenile specimen with valves still articulated, No. 23258. B - almost complete left valve with proximal part of telson, No. 23259. $\bullet$ C - isolated telson, No. 23260. D - posterior half of a left valve, with telson, No. 23262. $\bullet$ E - posteroventral part of a right valve with telson, No. 23261. $\bullet \mathrm{F}-$ left valve, with well preserved ventral border, and proximal part of telson, No. 23244 . $\bullet \mathrm{G}-\mathrm{incom}$ plete, large left valve with partly preserved ornament, No. $23245 . \bullet \mathrm{H}$ - anterior part of a left valve, No. 23263 . $\bullet$ I - isolated telson in dorsal view with longitudinal furrows, and the right row of lateral spinules, No. 23326. $\bullet \mathrm{J}, \mathrm{K}-$ two isolated telson showing the lateral row of spinules, No. 23249 and 23250 , respectively. $\bullet \mathrm{L}$ - poorly preserved tail piece, with the proximal part of a stylet still connected, No. 23251 . $\bullet \mathrm{M}$ - tail piece in ventral view, still connected to the last abdominal somite; note the length of the right stylet and the presence of lateral spinules up to the extremity of the telson, No. 23252. 
Table 2. List of Ordovician phyllocarid taxa drawn from the literature. The column 'M' (Material) gives the nature of the original specimens upon which the corresponding taxa were described: $\mathrm{CS}$ - complete specimens; $\mathrm{C}$ - carapace; $\mathrm{C}+\mathrm{TP}$ - carapace and tail piece; $\mathrm{C}+\mathrm{A}-\mathrm{carapace}$ and abdominal segments; F - isolated furcal rami. Asterisk indicates type species.

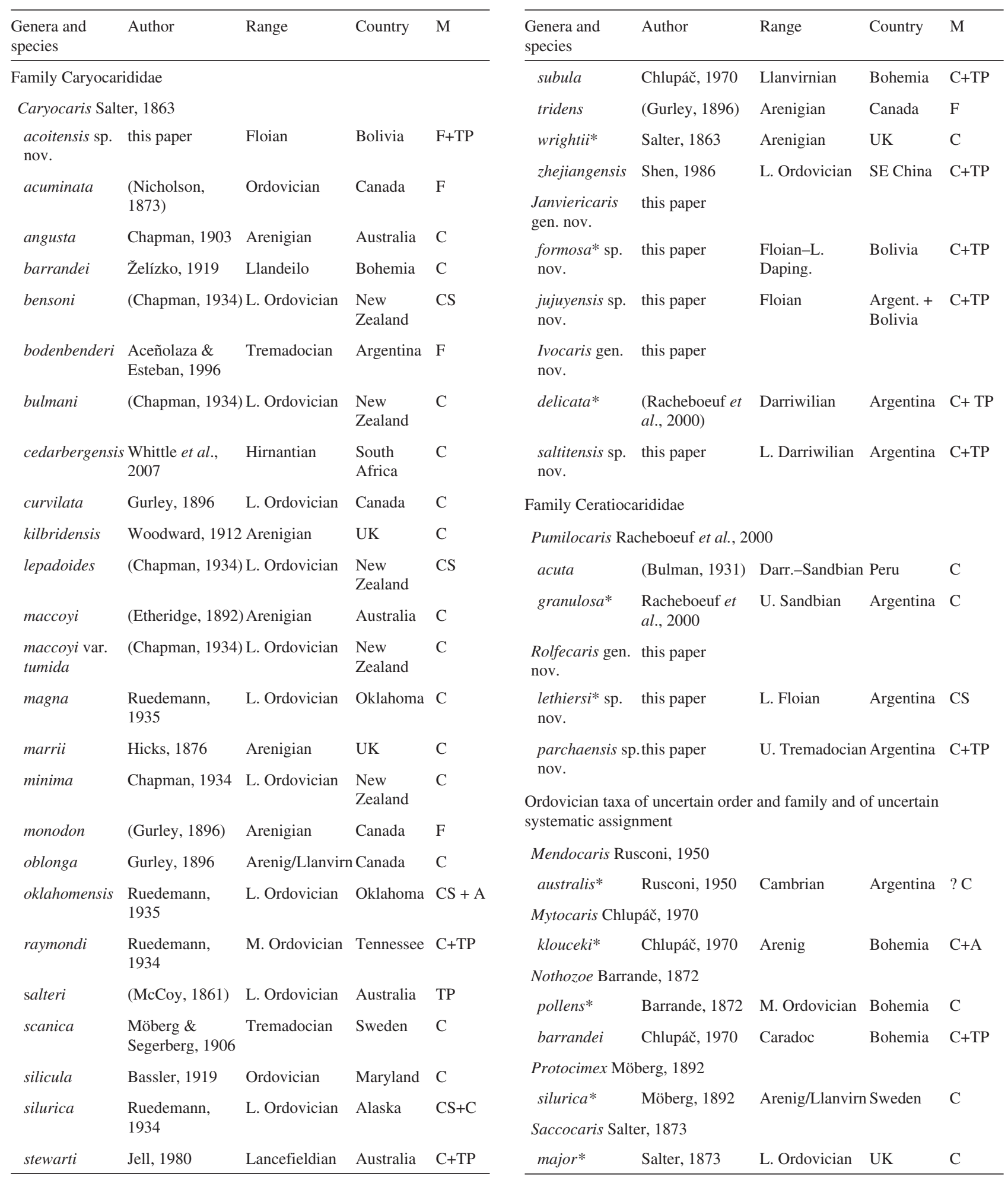



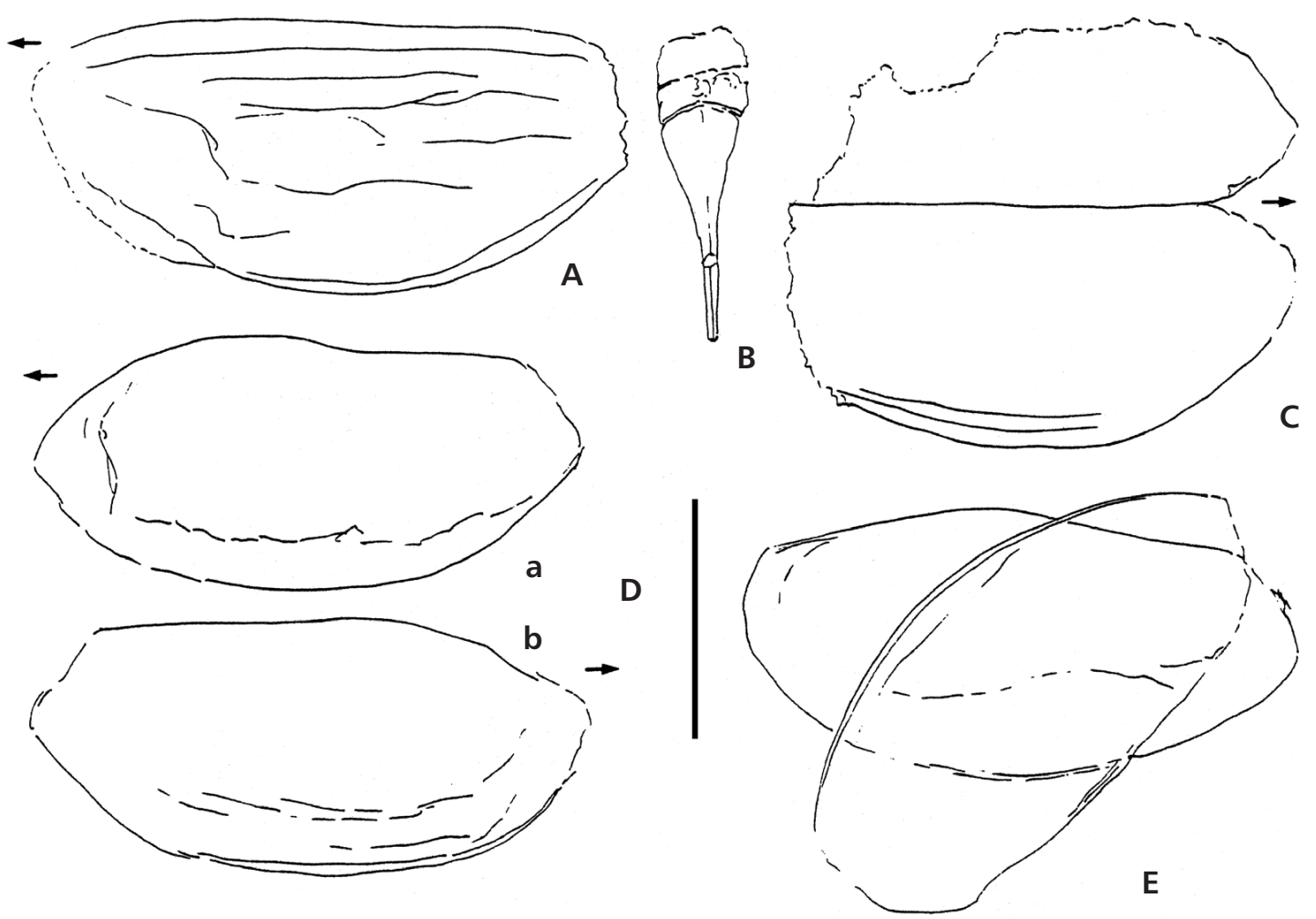

Figure 16. Rolfecaris parchaensis sp. nov. Camera lucida drawings of five carapaces and one tail piece. All specimens from the locality Guaico Hondo. Parcha Formation, Araenograptus murrayi and Hunnegraptus copiosus Zones (late Tremadoc). • A - left valve, holotype, No. 23231. • B - incomplete tail piece (telson) in dorsal view, still connected to the two last abdominal somites, No. 23233. $\bullet$ C - incomplete, still articulated carapace, No. 23235. - D - the two valves, right ( $\mathrm{Da}$ ) and left ( $\mathrm{Db}$ ) of a single carapace, No. 23234, and 23237, respectively. $\bullet$ E - right and left valves of a single (?) carapace, No. 23238. Scale bar $=3 \mathrm{~mm}$.

shale facies from the Tremadocian to the middle Katian, as it also results from the effects of currents, temperature of water, etc. More acurate taxonomic studies are needed, especially regarding old, poorly described species. Most of the species previously assigned to the genus Caryocaris and listed in Table 2 are in need of immediate further thorough revision for their taxonomic identity, their assignment, their age, their geographic distribution as well as their vertical range. Several taxa are probably junior synonyms. Such work would lead to a more precise stratigraphic range for each taxon and will undoubtedly make Ordovician phyllocarids and among them representatives of the Family Caryocarididae, a more reliable, helpful tool, for both biostratigraphic and palaeobiogeographic considerations during the Ordovician. Evolutionary tendencies within the Family Caryocarididae will be dealt with in another paper (Racheboeuf \& Crasquin, in press). An exhaustive, detailed, worldwide revision of all Ordovician phyllocarid remains in collections, using new, actualized biostratigraphical data, associated with complementary field sampling when necessary, would be indispensable to evaluate the evident potential biostratigraphical and biogeographical value of Ordovician phyllocarids.

\section{Acknowledgements}

This work could not have been finalized without the help of many colleagues. J.L. Benedetto (Universidad Nacional de Córdoba), G. Ortega (CONICET, Universidad Nacional de Córdoba), B. Toro (Universidad de Mendoza) and B. Waisfeld (Universidad de San Juan) in Argentina; R. Suarez-Soruco and R. Cespedes (Museo Alcide d'Orbigny, Cochabamba) in Bolivia; W.D.I. Rolfe (Edinburgh), A.A. Page and R.J. Whittle (University of Leicester) in the United Kingdom; P. Budil and J. Frýda (Czech Geological Survey, Prague) in the Czech Republic; J. Deutsch (Université Paris VI), and D. Guinot (MNHN, Paris) in France are greatly acknowledged for their help during field work, the loan of specimens and discussions regarding the hierarchy of characters. The authors are greatly indebted to the two reviewers, J.-C. Gutiérrez-Marco (Universidad Complutense, Madrid) and J. Vannier (Université Claude-Bernard Lyon 1) for their comments and criticism which greatly improved the manuscript. Y. Candela (NMS, Edinburgh) and his wife kindly accepted responsibility to revise and correct the English language of the text. This work was supported by the ECOS-Sud grant A99U03, 2000-2002. The authors are also indebted to CONICET, to the Agencia de Promoción Científica y Tecnológica and Universidad Nacional de La Pampa for financial support. 


\section{References}

ACEÑOLAZA, F.G. 1966. Geología estratigráfica de la región de la sierra de Cajas, Departamento Humahuaca, provincia de Jujuy. 143 pp. Unpublished doctoral thesis, Universidad Nacional de Córdoba.

ACEÑOLAZA, F.G. \& ESTEBAN, S. 1996. Filocáridos (Crustacea) en el Tremadociano del Sistema de Famatina, Provincia de La Rioja, Argentina. Memorias del XII Congreso Geológico de Bolivia, Tarija 28, 1-288.

ACEÑolaza, F.G., Gorustovich, S. \& Solis, J. 1976. El Ordovícico del río La Alumbrera, Departamento Tinogasta, Provincia de Catamarca. Ameghiniana 13, 269-288.

ACEÑOlaZA, F.G. \& GuTiÉRREZ-MARCO, J.C. 2000. Graptolitos de la Formación Portezuelo de las Minitas (Ordóvicico Inferior) del Sistema de Famatina, La Rioja, Argentina. Boletín de la Academia Nacional de Ciencias, Córdoba 64, 17-26.

AHLFELD, F. \& BRANISA, L. 1960. Geología de Bolivia. Revista del Museo de La Plata, N.S. 3(19), 5-370.

Albanesi, G., Esteban, S.B. \& BARNES, C.R. 1999. Conodontes del intervalo del límite Cámbrico-Ordovícico en la Formación Volcancito, Sistema de Famatina, Argentina. Temas Geológico-Mineros ITGE 26(52), 1-526.

AlbANesi, G., EstebAn, S.B., ORTEGA, G., HÜNICKEN, M. \& BARNES, C.R. 2005. Bioestratigrafía y ambientes sedimentarios de las formaciones Volcancito y Bordo Atravesado (Cámbrico Superior-Ordóvicico Inferior), Sistema de Famatina, provincia de La Rioja. Associación Geológica Argentina, Serie D, Publicación Especial 8, 41-64.

AlbANEsi, G. \& ORTEGA, G. 2002. Advances on conodontgraptolite biostratigraphy of the Ordovician System of Argentina, 143-165. In ACEÑOLAZA, F.G. (ed.) Aspects of the Ordovician System in Argentina. Serie de Correlación Geológica 16.

AstinI, R. 1992. Tectofacies ordovícicas y evolución de la cuenca eopaleozoica de la Precordillera Argentina. Estudios Geológicos 48, 315-327.

ASTINI, R. 1994. Análisis secuencial y paleoambientes de las pelitas negras (aloformación Gualcamayo) que suprayacen a las sucesiones carbonáticas eo-ordovícicas en la Precordillera argentina. Revista de la Asociación Geológica Argentina 49, $71-84$.

ASTINI, R. 2001. Nuia y Girvanella a través de la transición cambro-ordovícica (Formación Volcancito) en el Famatina: significado paleoambiental, paleoclimático y paleogeográfico. Ameghiniana 38, 243-255.

AstinI, R. 2003. The Ordovician Proto-Andean Basins, 75-90. In BENEDETTO, J.L. (ed.) Ordovician Fossils of Argentina. Secretaría de Ciencia y Tecnología, Universidad Nacional de Córdoba.

BALdis, B.A., BERESI, M., BordonARO, O. \& VACA, A. 1984. The Argentine Precordillera as a key to the Andean structure. Episodes 17, 14-19.

BARRANDE, J. 1872. Système silurien du centre de la Bohême, I. Prague \& Paris.

BARROIS, C. 1891. Mémoire sur la faune du grès armoricain. Annales de la Société géologique du Nord 19, 134-237.

BAssett, M.G. \& Berg-MAdSEN, V.D. 1993. Protocimex: a phyllocarid crustacean, not an Ordovician insect. Journal of Paleontology 67, 144-147.

BASSLER, R.S. 1919. Report on the Cambrian and Ordovician formations of Maryland. Maryland Geological Survey, Special Paper, 1-424, 58 pls.

BouCOT, A.J. 1975. Evolution and extinction rate controls. 427 pp. Elsevier, Amsterdam.

BRANISA, L. 1965. Los fosiles guías de Bolivia. I. Paleozoico. Boletin del Servicio Geológico de Bolivia 6, 1-282.

BRUSSA, E. \&. Astini, R. 1996. La Biozona de Undulograptus austrodentatus en la Formación Gualcamayo, quebrada de Los Saltitos, suroeste de Guandacol, Precordillera Argentina. Reunión Anual de Comunicaciones de la Asociación Paleontológica Argentina, Córdoba. Ameghiniana 34(1), 116.

BRUSSA, E. \& FlORES, L. In press. Darriwilian (Middle Ordovician) and Sanbian (Upper Ordovician) graptolite faunas of the Gualcamayo and Las Vacas Formations, Los Saltitos Creek, San Juan Precordillera, Argentina. Acta Geologica Sinica.

Brussa, E., Mitchell, C., OrtegA, G. \& Astini, R. 2003 b. Middle Ordovician graptolite biostratigraphy from the Los Azules Formaton at Los Gatos Creek, Central Precordillera, Argentina. Proceedings $7^{\text {th }}$ International Graptolite Conference - Field Meeting Subcommission on Silurian Stratigraphy, Serie de Correlación Geológica 18, 21-25.

Brussa, E., TORO, B.A. \& BENEDETTO, J.L. 2003a. Biostratigraphy, 75-90. In BENEDETTO, J.L. (ed.) Ordovician Fossils of Argentina. Secretaría de Ciencia y Tecnología, Universidad Nacional de Córdoba.

BULMAN, O.M.B. 1931. South American graptolites, wih special reference to the Nordenskiöld Collection. Arkiv för Zoologi $22 A(3), 1-111$.

CAMACHO, H.H. 1975. Invertebrados Fósiles. $2^{\text {nd }}$ edition. 707 pp. Editorial Universitaria de Buenos Aires.

CHAPMAN, F.C. 1903. New or little-known Victorian fossils in the National Museum, Melbourne. Proceedings of the Royal Society of Victoria 16, 104-122.

ChapMAN, F.C. 1934. On some phyllocarids from the Ordovician of Preservation Inlet and Cape Providence, New Zealand. Transactions of the New Zealand Institute 64, 105-114.

CHLUPÁČ, I. 1970. Phyllocarid crustaceans of the Bohemian Ordovician. Sborník geologických věd, Paleontologie 12, 41-75.

CHLUPÁČ, I. 2003. Phyllocarid crustaceans from the Middle Ordovician Šárka Formation at Praha-Vokovice. Bulletin of Geosciences 78, 107-111.

CHURKIN, JR. M. 1966. Morphology and stratigraphic range of the phyllocarid crustacean Caryocaris from Alaska and the Great Basin. Palaeontology 9, 371-380.

Claus, C. 1888. Über den Organismus der Nebaliden und die systematische Stellung der Leptostraken. Arbeiten aus dem zoologische Institut der Universität Wien und der zoologischen Station in Triest 8, 1-148.

COIRA, B. \& PÉREZ, B. 2002. Peperitic textures of Ordovician dacitic synsedimentary intrutions in Argentina Puna Highland: clues to emplacement conditions. Journal of Volcanology and Geothermal Research 114, 165-180. DOI 10.1016/S0377-0273(01)00291-8

COlletTE, J.H. \& RUDKIN, D.M. In press. A new phyllocarid crustacea from the Eramosa Lagerstätte (Silurian - Wenlockian), Ontario, Canada, and a revised interpretation of abdomi- 
nal 'scales' in Ceratiocaris 'papilio'. Transactions of the Royal Society of Edinburgh.

EKSTRÖM, G. 1937. Upper Didymograptus Shale in Scania. Sveriges Geologiska Undersökning Serie C, Afhandlingar och Uppsatser 403, 1-53.

ESTEBAN, S.B. 1996. Los primeros trilobites ciclipígidos en el Ordovícico de Argentina (Formación Volcancito, Sistema de Famatina). Ameghiniana 33, 57-64.

ESTEBAN, S.B. 1999. Cyclopygid trilobites and associated facies from the Ordovician of the Famatina basin (Northwestern Argentina): Paleogeographic and evolutionary implications. Acta Universitatis Carolinae, Geologica 43, 377-379.

EstebAn, S.B. 2002. The Early Ordovician in the Sistema de Famatina: stratigraphic and geotectonic framework. In ACEÑOlaZA, F.G. (ed.) Aspects of the Ordovician System in Argentina. Correlación Geológica, Tucumán 16, 27-40.

ESTEBAN, S. \& GuTIÉRREZ-MARCO, J.C. 1997. Graptolitos del Tremadoc del Sistema de Famatina (Argentina). $5^{\circ}$ Reunión Internacional del Proyecto 351 PICG 'Paleozoico Inferior del Noroeste de Gondwana'. Abstracts, 59-63.

ETHERIDGE, R. JR. 1892. A monograph of the Carboniferous and Permo-Carboniferous invertebrata of New South Wales, Part II. Echinodermata, Annelida and Crustacea. New South Wales Geological Survey, Memoir, Palaeontology 5, 65-131.

GuRLEY, R. R. 1896. North American graptolites: new species and vertical range. The Journal of Geology 4, 63-301.

GutiÉRREZ-MARCO, J.C. \& EstebAN, S. 2005. Graptolitos del Tremadociense (Ordovícico Inferior) de la Formación Volcancito, Sistema de Famatina (La Rioja, Argentina). Revista Espańola de Paleontología 20(11), 65-118.

GutiÉRREZ-MARCO, J.C., GÓMEZ, C. \& SARMIENTO, G.N. 2006. El Ordovícico dela Cordillera colombiana y su correlación con Perú, 623-626. In CARLOTTO, V., CÁRDENAS, J., SOLER, P. \& JACAY, J. (eds) XIII Congreso peruano de Geología. Sociedad Geológica del Perú, Lima, Publicación Especial 7.

HANNIBAL, J.T., \& FELDMANN, R.M. 1996. Caryocaris (Crustacea: Phyllocarida) from the Ordovician of the Cordillera Oriental of Souhern Bolivia. Kirtlandia 49, 7-11.

HANNIBAL, J.T. \& FELDMANN, R.M. 1997. Phyllocarid crustaceans from a Middle Ordovician Black Shale Within the Ames Structure, Northwest Oklahoma. Oklahoma Geological Survey, Circular, 100, 370-373.

HARRINGTON, H.J. \& KAY, M. 1951. Cambrian and Ordovician faunas of Eastern Colombia. Journal of Paleontology 25, 655-668.

HARRINGTON, H.J. \& LEANZA, A.F. 1957. Ordovician Trilobites of Argentina. University of Kansas Press, Special Publication $1,1-259$.

HICKS, H. 1876. In MARR, J.E. Fossiliferous Cambrian shales near Caernarvon. Quarterly Journal of the Geological Society of London 32.

HuGHES, C.P. 1980. A brief review of the Ordovician faunas of northern South America. Actas del Segundo Congreso Argentino de Paleontología y Bioestratigrafía y Primer Congreso Latinoamericano de Paleontología, Buenos Aires (1978)1, 11-22.

JELL, P.E. 1980. Two arthropods from the Lancefieldian (La 1) of central Victoria. Alcheringa 4, 37-46. DO] $10.1080 / 03115518008558979$
LATREILle, P.A. 1806. Genera Crustaceorum et Insectorum secundum ordinem naturalem in familias doisposita, iconibus exemplurisque plurimis explicata. T. 1, 302 pp., pls 1-16. Paris \& Argentorati.

LAUBACHER, G. 1974. Le Paléozoïque inférieur de la Cordillère orientale du sud-est du Pérou. Cahiers de l'ORSTOM, Série Géologique 6(1), 29-40.

LEGRAND-SMITH, A. \& HANNIBAL, J.T. 2000. Rock shrimp. Explorer 41(2), 11-13.

LEVY, R. 1971. Noticia sobre el hallazgo de apendices ventrales de trilobites en la Formación Parcha (Salta). Revista de la Asociación Paleontológica Argentina 8(2), 73-76.

MANCA, N. 1991. Organismos planctónicos en el Tremadociano inferior de los alrededores de la Quebrada de Humahuaca, Provincia de Jujuy, Agentina. Revista del Instituto de Geología y Minería, Jujuy 8, 141-150.

MartíneZ, M., BrussA, E., PéreZ, B. \& CoIRA, B. 1999. El Ordovícico de la sierra de Quichagua (Puna nororiental argentina): litofacies volcanosedimentarias y graptofaunas. (Volcanic sedimentary lithofacies and graptolites from the sierra de Quichagua, Ordovician of the Northeastern Puna of Argentina. XIV Congreso Geológico Argentino, I, 347-350.

MCCOY, P. 1849. On the classification of some British fossil Crustacea, with notices of new forms in the University of Cambridge. The Annals and Magazine of Natural History 4.

MendeZ, V. 1973. Geología de la comarca de Mina 'Aguilar' y alrededores, Departamento Humahuaca, Provincia de Jujuy. Revista de la Asociación Geológica de Argentina 28, 319-330.

MÖBERG, J.C. 1892. Om en Hemipter fran Sveriges Undre Graptolitskiffer. Geologiska Föreningens i Stockholm Förhandlingar 14, 121-124.

MÖBERG, J.C. \& SEGERBERG, O. 1906. Bidrag till kännedomen om Ceratopygeregionen med sörskild hänsyn till dess utveckling i Fogelsångstrakten. Meddelande från Lunds Geologiska Faltklubb, new series 2(7), 1-113.

NiCHOLSON, H.A. 1873. On some fossils from the Quebec Group of Point Lévis, Quebec. The Annals and Magazine of Natural History 11, 133-143.

ORTEGA, G. 1987. Las graptofaunas y los conodontes de la Formación Los Azules, cerro Viejo, zona de Huaco, departamento Jáchal, San Juan. 210 pp. Unpublished tesis doctoral, Facultad de Ciencias Exactas, Físicas y Naturales, Universidad Nacional de Córdoba.

ORTEGA, G. \& AlBANESI, G. 2002. Bioestratigrafía de graptolitos y conodontes del Tremadociano tardío de la Cordillera Oriental, Argentina. $15^{\text {th }}$ Congreso Geológico Argentino I, 542-547.

ORTEGA, G. \& RickARDS, B. 2003. A Darriwilian (Middle Ordovician) graptolite fauna of the Lower Member of the Los Azules Formation, Cerro Viejo, San Juan Precordillera, Argentina. Proceedings $7^{\text {th }}$ International Graptolite Conference - Field Meeting Subcommission on Silurian Stratigraphy, Serie de Correlación Geológica 18, 21-25.

PACKARD, A.S. 1879. A monograph of the Phyllopod Crustacea of north America, with remarks on the order phyllocarida. $12^{\text {th }}$ Report of the U.S. Geological Survey Territories 12, 295-592.

Page, A., Wilby, P.R., Mellish, C., Williams, M. \& ZALASIEWICZ, J.A. In press. Dawsonia Nicholson: linguliform 
brachiopods, crustacean tail-pieces and a problematicum rather than graptolite ovarian vesicles. Transactions of the Royal Society of Edinburgh.

RACHEBOEUF, P.R. 1994. Silurian and Devonian phyllocarid crustaceans from the Massif armoricain, NW France. Revue de Paléobiologie 13, 281-305.

RACHEBOEUF, P.R. 2004. Phyllocarid crustaceans, 257-260. In WebBy, B.D., PARIS, F., DRoser, M. \& PERCIVAl, I.G. (eds) The Great Ordovician Biodiversification Event. Columbia University Press.

RACheboeUf, P.R. \& CRASQUin, S. In press. The Ordovician caryocaridid phyllocarids (Crustacea): diversity and evolutionary tendencies. Neues Jahrbuch für Geologie und Paläontologie.

Racheboeuf, P.R., VAnnier, J. \& ORTega, G. 2000. Ordovician phyllocarids (Arthropoda; Crustacea) from Argentina. Paläontologische Zeitschrift 74, 317-333.

RAMOS, V.A. 1970. Geología de los primeros contrafuertes de la puna saltojujeña, entre San Antonio de los Cobres y El Moreno, provincias de Salta y Jujuy. Unpublished doctoral tesis, Universidad de Buenos Aires.

RAmos, V.A. 1984. Filocáridos (Crustacea) del Ordovícico Argentino. Actas del III ${ }^{\circ}$ Congreso Argentino de Paleontología y Bioestratigrafía, Corrientes (1982), 29-38.

ROLFE, W.D.I. 1962. Grosser morphology of the Scottish Silurian phyllocarid crustacean Ceratiocaris papilio Salter in Murchison. Journal of Paleontology 36, 912-932.

RoLFE, W.D.I. 1969. Phyllocarida, R296-R331. In MoORE, R.C. \& TEICHERT, C. (eds) Treatise on Invertebrate Paleontology. Part R. Arthropoda 4(1). 398 pp. Geological Society of America \& University of Kansas Press, Boulder, Colorado \& Lawrence, Kansas.

RuedemanN, R. 1934. Paleozoic plankton of North America. Geological Society of America, Memoir 2, 1-141.

RUEDEMANN, R. 1935. Silurian phyllocarid crustaceans from Oklahoma. Journal of Paleontology 9, 447-448.

RUSCONI, C. 1950. Nuevos trilobitas y otros organismos del Cámbrico de Canota. Revista del Museo de Historia Natural de Mendoza 4, 85-94.

Rushton, A.W.A. \& WiLliams, M. 1996. The tail-piece of the crustacean Caryocaris wrightii from the Arenig rocks of England and Ireland. Irish Journal of Earth Sciences 15, 107-111.

SALTER, J.W. 1863. Note on the Skiddaw Slate fossils. Quarterly Journal of the Geological Society of London 19, 135-140.

SCOTESE, C.R. \& MCKERROW, W.S. 1990. Revised world maps and introduction, 1-21. In MCKeRrow, W.S. \& SCOTESE, C.R. (eds) Palaeozoic Palaeogeography and Biogeography. Geological Society of London, Memoir 12, 1-435.

SHEN, Y.-B. 1986. Caryocaris from the Lower Ordovician of Jiangshan, Zhejiang. Kexue Tongbao 31, 765-769.

STRAELEN, V. VAN \& SCHMITZ, G. 1934. Crustacea Phyllocarida
(= Archaeostraca). Fossilium Catalogus, I. Animalia 64, $1-246$.

SÚAREZ-SORUCO, R. 1976. El sistema Ordovícico en Bolivia. Revista Técnica YPFB 5, 111-223.

TORO, B. 1999. Graptolitos arenigianos de Santa Victoria, Cordillera Oriental, Argentina. Bioestratigrafía y paleogeografía. $14^{\circ}$ Congreso Geológico Argentino I, 339-342.

TORO, B. \& Brussa, E. 2003. Graptolites, 441-505. In BENEDETTO, J.L. (ed.) Ordovician Fossils of Argentina. Secretaría de Ciencias y Tecnología, Universidad Nacional de Córdoba.

TORTELLO, M.F. \& ESTEBAN, S.B. 1995. Un trilobite agnóstido en el Ordovícico de la región de Bordo Atravesasdo (Cuesta de Miranda), Provincia de La Rioja, Argentina. Actas del VI Congreso Argentino de Paleontología y Bioestratigrafía, Trelew, 271-275.

TORTELLO, M.F. \& ESTEBAN, S.B. 2003. Lower Ordovician stratigraphy and trilobite faunas from the southern Famatina Range, La Rioja, Argentina. Special Papers in Palaeontology 70, 213-239.

TRUMPY, D. 1943. Pre-Cretacerous of Colombia. Bulletin of the Geological Society of America, 54(9), 1281-1304.

TURNER, J.C.M. 1960a. Faunas graptolíticas de América del Sur. Revista de la Associación Geológica Argentina 14, 5180.

TURNER, J.C.M. 1960b. Estratigrafía del tramo medio de la Sierra del Famatina y adyacencias (La Rioja). Boletín de la Academia Nacional de Ciencias de Argentina 42, 77-126.

VANNIER, J., BOISSY, P. \& RACHEBOEUF, P.R. 1997. Locomotion in Nebalia bipes: a possible model for Palaeozoic phyllocarid crustaceans. Lethaia 30, 89-104.

VANNIER, J., RACHEBOEUF, P.R., BRUSSA, E., WILliams, M., Rushton, A.W.A., SERVAIS, T. \& Siveter, D.J. 2003. Cosmopolitan arthropod zooplankton in Ordovician seas. Palaeogeography, Palaeoclimatology, Palaeoecology 195, 173-191. DOI 10.1016/S0031-0182(03)00307-9

WAisfeld, B., VAcCARi, N., ToRo, B., Rubinstein, C. \& Astini, R. 2006. Revisión de la Biozona de Ogygiocaris araiorhachis (Trilobita, Tremadociano tardío) en la región de Pascha-Incamayo, Cordillera Oriental, Argentina. Parte 1: Bioestratigrafía. Ameghiniana 43(4), 717-728.

Whittle, R.J., GABbott, S.E., Aldridge, R.J. \& Theron, J.N. 2007. Taphonomy and palaeocology of a Late Ordovician caryocaridid (Crustacea, Phyllocarida) from the Soom Shale Lagerstätte, South Africa. Palaeogeography, Palaeoclimatology, Palaeoecology 251, 383-397.

DOI 10.1016/j.palaeo.2007.04.006

WOODWARD, H. 1912. Note on a new species of Caryocaris ( $C$. kilbridensis) from the Arenig rocks of the Kilbride Peninsula. Quarterly Journal of the Geological Society of London 68, 99-101.

ŽELíZKO, J.V. 1919. Nálezy phyllocaridů ve spodním siluru západočeském. Rozpravy České akademie věd a umění, Třida II (matematicko-přrirodovědná) 27, 32. 